\title{
Characterization of a plant dietary supplement ("multimistura") capacities, used in Mozambique to fight nutritional insecurity
}

\author{
Caracterização do potencial de uma multimistura vegetal utilizada como suplemento alimentar \\ na luta contra a insegurança nutricional em Moçambique
}

\author{
Filipa Neto ${ }^{1,2^{* * *}}$, Margarida Moldão-Martins², Luis F. Goulao ${ }^{1, \mathbf{w}, *}$ \\ ${ }^{1}$ Instituto de Investigação Científica Tropical (IICT, IP), Tapada da Ajuda 1349-017 Lisboa, Portugal \\ ${ }^{2}$ LEAF/Instituto Superior de Agronomia (ISA/ULisboa), Tapada da Ajuda 1349-017 Lisboa, Portugal \\ Email:luisfgoulao@gmail.com
}

\begin{abstract}
${ }^{\circledR}$ Present address: LEAF/Instituto Superior de Agronomia (ISA/ULisboa), Tapada da Ajuda 1349-017 Lisboa, Portugal
**Este artigo foi apresentado como comunicação oral no seminário "Segurança Alimentar e Nutricional na Medicina Tropical - caminhos comuns na CPLP", realizado como encontro satélite do $3^{\circ}$ Congresso Nacional de Medicina Tropical, no dia 17 de Abril de 2015
\end{abstract}

\begin{abstract}
The use of food dietary supplements, commonly called "multimisturas", has been adopted, in developing countries, as a strategy to combat micronutrient deficiency in the population.. The goal of this work was to study the composition and nutritional potential of a "multimistura" that was developed and used in a vulnerable community of Nampula, Mozambique to fight micronutrient deficiency in pregnant or lactating women and in children up to 8 years old. The micronutrient composition of the "multimistura" developed with locally available products did not show statistically significant differences when compared to commercial food supplements used in industrialized countries. Taking in account the composition results and the nutritional requirements of each target group, it was observed that the currently recommended daily intake should be, at least, doubled to fulfil the nutritional needs of each of the groups. The exception regards Children in the 1-3 year old group, would be an exception, as the doubling of ingestion would be detrimental since it would exceed the tolerable daily intake of magnesium. This work allowed the suggestion of some procedures aimed at balancing the supplement nutritional composition to leverage adequate levels of household nutritional security in the target community.
\end{abstract}

Keywords: dietary supplement, food security, hidden hunger, Mozambique, multimistura.

\section{Resumo}

Em países em desenvolvimento, uma das formas de combate à carência de micronutrientes da população é o recurso a suplementos alimentares, comummente chamados de multimisturas, definidas como o produto obtido através da secagem, torrefação, moagem e mistura de ingredientes de origem vegetal. Neste trabalho pretendeu-se estudar a composição e adequabilidade de uma dessas multimisturas, desenvolvida numa comunidade vulnerável em Nampula,Moçambique, e utilizada no combate da carência de micronutrientes em grávidas, lactantes e crianças até aos 8 anos. A composição de micronutrientes da multimistura, desenvolvida com base em produtos locais, não se mostrou estatisticamente diferente da descrita em suplementos alimentares comerciais usados em países industrializados. Com base nas determinações efetuadas e nas necessidades nutricionais de cada grupo etário, constatou-se que as doses diárias recomendadas atualmente são nutricionalmente insuficientes sendo necessário, no mínimo, duplicar a quantidade de multimistura ingerida por cada um dos grupos. A exceção é o grupo das crianças dos 1 aos 3 anos onde a duplicação da dose seria prejudicial, pois implicaria que a dose diária aceitável de magnésio fosse ultrapassada. São sugeridas ainda algumas medidas para otimizar a composição da multimistura, de modo a garantir adequados níveis de segurança nutricional às famílias das comunidades-alvo.

Palavras-Chaves: Insegurança alimentar, Fome oculta, Moçambique, Multimistura, Suplemento alimentar. 


\section{Introduction}

"Hunger" is described as malnutrition caused by lack of physical or budgetary access to safe and nutritious foods to ensure daily needs ${ }^{1,2}$. Food security is rooted in four pillars: availability, access, use and stability ${ }^{3}$. Access to food and dietary quality (or lack of ) have a profound impact on the health and well-being of people and society, severely affecting the capacity for socioeconomic development ${ }^{4}$. Children and fertile women are the most susceptible groups ${ }^{5}$. In 2008, maternal and child malnutrition was responsible for about 3.5 million world deaths ${ }^{6}$. A child's malnutrition consequences are reflected in adult life and transmitted to the subsequent generation, when malnourished women have their own children. At time of conception and during pregnancy, the women's nutritional status is crucial to good development of the fetus. Moreover, proper nutrition during the child's earliest two years sets a pattern for the remaining lifespan. Thus, if during pregnancy and the first 24 months, the nutritional needs of the baby are not met, irreversible physical and mental impairments are more likely to occur ${ }^{7}$. A country with high rates of child and maternal malnutrition faces an uncertain future with respect its workforce health, hence, compromising opportunities for socioeconomic development ${ }^{8}$. In 2012, about 99 million children under 5 years old suffered from malnutrition, the majority of which were living in south Asia and sub-Saharan Africa'. The conception of "hidden hunger" is used to describe chronic deficiency of micronutrients (vitamins and minerals) as a result of poor quality or balance of food intake. "Hidden Hunger" is estimated to affect about 2.5 to 1,000 million people worldwide ${ }^{10}$ and its effect exerts a profound economic impact in the communities due to the commonly associated low human individual productivity ${ }^{11}$. Thus, the phenomenon of hunger is unequivocally linked with development ${ }^{12}$.

Mozambique has a population estimated at about 24.4 million people ${ }^{13}$, and is considered among of the world's poorest countries, with a GDP per capita of $\$ 1.200$ (USA dollars) in $2013^{14}$ and a very low value in the Human Development Index. In the period from $2010-2012,39.2 \%$ of this country's population was undernourished, and during 2008-2012, 14.9\% of children under five years old showed growth disturbances ${ }^{15}$. The Mozambican diet is poorly diversified, low-calorie, low in lipids and proteins ${ }^{16}$, and scarce in essential micronutrients ${ }^{17}$. It can be characterised by high consumption of cereals and starch-rich roots and low consumption of products of animal origin and of fruits and vegetables. The common micronutrient deficiencies amongst the Mozambican population are related to vitamins A, D, E,

\section{Introdução}

O termo "fome" é utilizado para descrever a malnutrição originada pela insegurança alimentar, onde as pessoas não têm acesso físico e económico a alimentos seguros e nutritivos que assegurem as suas necessidades diárias ${ }^{1,2}$. A segurança alimentar assenta em quatro pilares: disponibilidade, acesso, utilização e estabilida$\mathrm{de}^{3}$. O acesso a alimentos e a qualidade da alimentação (ou falta dela) têm um profundo impacto na saúde e no bem-estar das pessoas, logo no capital humano, afetando gravemente a capacidade de desenvolvimento de uma sociedade ${ }^{4}$. As crianças e as mulheres em idade fértil são os grupos mais suscetíveis a esta problemática ${ }^{5}$. Em 2008 o problema da subnutrição materna e infantil foi responsável por cerca de 3,5 milhões de mortes em todo o mundo ${ }^{6}$. As consequências da subnutrição infantil refletem-se na vida adulta e são passadas para a geração seguinte quando mulheres subnutridas têm os seus próprios filhos. $\mathrm{O}$ estado nutricional da mulher na altura da conceção e durante o tempo de gravidez são determinantes para o desenvolvimento saudável do feto. Aliado a isto, a alimentação adequada nos dois primeiros anos de vida da criança define um padrão de saúde para o resto da vida. Assim, se durante o tempo de gestação e nos primeiros 24 meses de vida a criança não suprimir convenientemente as suas necessidades nutricionais, esta terá grande probabilidade de sofrer danos físicos e mentais irreversíveis ${ }^{7}$. Um país com elevadas taxas de malnutrição materna e infantil enfrenta, assim, um futuro incerto no que diz respeito à saúde da sua força de trabalho, logo às oportunidades de desenvolvimento económico $^{8}$. Em 2012, cerca de 99 milhões de crianças com menos de 5 anos sofria de malnutrição, vivendo a grande maioria destas no Sul da Ásia e na África Subsariana9. O conceito de "fome oculta" é utilizado para descrever a deficiência crónica de micronutrientes (vitaminas e minerais), como consequência da má qualidade da alimentação. Calcula-se que este problema afete cerca de 2,5 mil milhões de pessoas em todo o mundo ${ }^{10}$. Os efeitos da "fome oculta" exercem um profundo impacto económico nas comunidades devido à baixa produtividade que regra geral estes indivíduos apresentam ${ }^{11}$, ligando de forma inequívoca o fenómeno da fome ao do desenvolvimento ${ }^{12}$.

Moçambique apresenta uma população de aproximadamente 24,4 milhões de pessoas ${ }^{13}$, sendo um dos países mais pobres do mundo, com um PIB per capita de $\$ 1,200$ (dólares americanos) em $2013^{14}$ e com um índice de desenvolvimento humano extremamente baixo. Entre 2010-2012, 39,2\% da população deste país era subnutrida e entre 2008-2012, 14,9\% das crianças com menos de cinco anos apresentava insuficiência pon- 
$\mathrm{K}$ and $\mathrm{B} 3$, iron, zinc, calcium and iodine $\mathrm{e}^{17}$. According to the 2013 Global Hunger Index (GHI) ${ }^{15}$, Mozambique is classified as having an alarming severity of hunger, with a value of 21.5, placing Mozambique in the 106th position among the 120 countries that comprise this ranking ${ }^{15}$.

In developing countries, fighting micronutrient deficiency includes increased consumption of plant-derived products as dietary supplements, commonly called "multimisturas". These products are obtained as the result of drying, roasting, grinding and mixing ingredients of vegetable origin, typically local and easily avail$\mathrm{able}^{18}$. Among the most frequently used ingredients are: bran (usually from wheat or rice), green leaves (beet, cassava, sweet potato, carrot, etc.), roots and stems, vegetable peels, fruits (banana, pumpkin, etc.), egg shell, or seeds (from sesame, watermelon, pumpkin, etc. $)^{18}$. The "multimisturas" were initially developed in Brazil in 1976, by Dr. Clara and Rubens Brandão ${ }^{19}$, and their use was widely spread ${ }^{20,21}$. The driver for manufacturing these supplements arose from the recognition that these routine foods are seldom present in the diets, even though they are often rich in vitamins and minerals ${ }^{22,23}$. The goal was to make it accessible to an entire population ${ }^{22,23}$, standing as a low-cost product with high nutritional value ${ }^{21}$. Some studies show that improving the health status of high-risk groups is possible in a short time, solely by increasing the consumption of plant-derived products ${ }^{24}$. In addition to their role in directly fighting malnutrition, plant products are rich in a wide range of low molecular weight secondary and biologically active metabolites, such as carotenes, phytosterols, glucosinolates, polyphenols and terpene compounds that exert beneficial functions to humans, acting as antioxidant, anticancer, antimicrobial, anti-inflammatory and anti-thrombotic ${ }^{25}$. However, to deliver an effective response to the nutritional needs of a given population to whom these supplements are intended, it is important to know its composition and nutrient concentration and its true effectiveness, quality and safety ${ }^{26}$.

The objective of this work was to determine the composition of a "multimistura" developed in local vulnerable communities of the Nampula province in Mozambique and its suitability in fighting lack of micronutrients in pregnant lactating women and in the diets of children up to 8 years old. To accomplish this, product stability, nutritional composition and physical-chemical characteristics were evaluated and the "multimistura" micronutrient content was compared with those reported in commercial supplements. Based on recommended daily intake (RDA's) for each target group, the estimated dera $1^{15}$. A dieta moçambicana é pouco diversificada, hipocalórica, pobre em lípidos e proteínas ${ }^{16}$ e escassa em micronutrientes essenciais ${ }^{17}$. Caracteriza-se por um elevado consumo de cereais e raízes de plantas ricas em amido e um baixo consumo de produtos animais e de fruta e vegetais. Os micronutrientes que mais comummente se apresentam em défice na população moçambicana são as vitaminas A, D, E, K e B3, o ferro, o zinco, o cálcio e o iodo ${ }^{17}$. De acordo com o Índice Global da Fome (IGF) de $2013^{15}$, Moçambique apresenta uma severidade da fome alarmante, com um valor de 21,5. Este resultado coloca Moçambique em $106^{\circ}$ lugar entre os 120 países que fazem parte deste ranking ${ }^{15}$.

Em países em desenvolvimento, e com o objetivo de combater a carência de micronutrientes através de um aumento do consumo de produtos vegetais, surgiram suplementos alimentares, comummente chamados de multimisturas, que se definem como o produto obtido através da secagem, torrefação, moagem e mistura de ingredientes de origem vegetal, usualmente locais e facilmente disponíveis ${ }^{18}$. Entre os alimentos mais utilizados para a produção destes suplementos encontram-se: farelos (usualmente trigo ou arroz), folhas verdes (mandioca, beterraba, batata doce, cenoura, etc.), raízes e caules de plantas, cascas de vegetais, frutos (banana, abóbora, etc.), casca de ovo e sementes (sésamo, melancia, abóbora, etc. $)^{18}$. As multimisturas foram inicialmente desenvolvidas no Brasil em 1976, pelos médicos Clara e Rubens Brandão ${ }^{19}$, tendo o seu uso sido amplamente difundido ${ }^{20,21}$. O fabrico destes suplementos surgiu da proposta de promover na alimentação habitual o uso de alimentos nem sempre tradicionalmente presentes nas dietas, mas ricos em vitaminas e minerais, que fossem acessíveis a toda a população ${ }^{22,23}$, criando um produto de baixo custo e com elevado valor nutricional ${ }^{21}$. Alguns estudos comprovam que é possível melhorar a saúde de grupos de risco, num curto espaço de tempo, unicamente aumentando o consumo de produtos vegetais ${ }^{24}$. Para além dos produtos vegetais atuarem no combate à subnutrição de forma direta, estes ainda contêm uma elevada gama de metabolitos secundários de baixo peso molecular e biologicamente ativos, como carotenóides, fitoesteróis, glucosinolatos, polifenóis e compostos terpénicos, que exercem atividades benéficas no organismo humano, do tipo antioxidante, anticancerígena, antimicrobiana, antiinflamatória e antitrombótica ${ }^{25}$. No entanto, para dar uma resposta eficiente às necessidades nutricionais da população a quem estes suplementos se destinam, torna-se fundamental conhecer a composição e concentração dos nutrientes presentes nas multimisturas e a sua real eficácia, qualidade e segurança ${ }^{26}$. 
daily dose of intake was estimated, allowing recommendations to be made for improved use.

\section{Material and methods}

\section{Plant materials}

The "multimistura" was produced with: moringa (Moringa spp.), pumpkin (Cucurbita spp.), rice (Oryza sativa), cassava (Manihot esculenta), sesame (Sesamum indicum), sweet potatoes (Ipomoea potatoes), baobab (Adansonia digitata) and green bananas (Musa acuminata). The plant organ selected and the percentage of each ingredient remain the unique knowledge of the religious congregation responsible for the project. After grinding with a mill (Retsch) with $1 \mathrm{~mm}$ mesh, the appearance of the product is shown in Figure 1. The commercial food supplements employed for micronutrient composition comparisons were: FDC Nutri- FDC VITAMINS ${ }^{\circledR}$, FDC Nutri Senior- FDC VITAMINS ${ }^{\circledR}$, FDC Nutri Kids- FDC VITAMINS ${ }^{\circledR}$, Pharmaton Vitality- Boehringer Ingelheim, Juvamine Top formJuvamine, Multivitamins AaZ-Ignoramus, CentrumCentrum ${ }^{\circledR}$, Centrum Woman- Centrum ${ }^{\circledR}$, Centrum Mother- Centrum ${ }^{\circledR}$ and Centrum Junior- Centrum ®. Comparisons considered solely the micronutrient composition determined for the "multimistura" and the counterpart indicated in the respective food supplement labels.

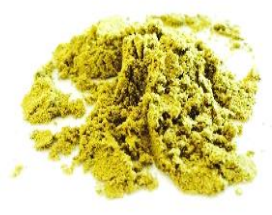

Figure 1/ Figura 1 - Aspect of the Product in study - "multimistura"/ Aspeto da multimistura em estudo.
O objetivo deste trabalho foi estudar a composição e adequabilidade de uma multimistura desenvolvida e utilizada no combate da carência de micronutrientes de grávidas, lactantes e crianças até aos 8 anos de comunidades locais vulneráveis na província de Nampula. Para tal, foi avaliada a estabilidade do produto, determinada a composição nutricional e características físico-químicas, comparada a composição em micronutrientes da multimistura com suplementos alimentares comerciais e estimada a dose diária adequada de multimistura, tendo por base as doses diárias recomendadas (DDR's) para cada grupo alvo, permitindo desenhar recomendações para uma utilização melhorada. Pretende-se apresentar um exemplo de como a cooperação científica e o diálogo multissetorial podem contribuir de forma direta para o desenvolvimento e para o bem-estar de populações vulneráveis.

\section{Material e Métodos}

\section{Produtos vegetais}

A multimistura em estudo foi produzida com: moringa (Moringa spp.), abóbora (Cucurbita spp.), arroz (Oryza sativa), mandioca (Manihot esculenta), sésamo (Sesamum indicum), batata-doce (Ipomoea batatas), embondeiro (Adansonia digitata) e banana verde (Musa acuminata). A parte da planta utilizada e a composição percentual de cada ingrediente na multimistura são do conhecimento exclusivo da congregação que a desenvolveu. $\mathrm{O}$ aspeto da multimistura após moagem num moinho (Retsch) com crivo de $1 \mathrm{~mm}$ apresenta-se na Figura 1. Os suplementos alimentares comerciais que foram utilizados para a comparação com a multimistura em estudo foram: FDC Nutri- FDC VITAMINS $®$, FDC Nutri Senior- FDC VITAMINS ${ }^{\circledR}$, FDC Nutri KidsFDC VITAMINS ${ }^{\circledR}$, Pharmaton Vitalidade- Boehringer Ingelheim, Juvamine Top Forma- Juvamine, Multivitaminas AaZ- Ignoramus, Centrum- Centrum ${ }^{\circledR}$, Centrum Mulher- Centrum ${ }^{\circledR}$, Centrum Materna- Centrum ${ }^{\circledR}$ e Centrum Junior- Centrum ${ }^{\circledR}$. A comparação foi realizada considerando exclusivamente a composição de micronutrientes determinada para a multimistura e indicada nos respetivos rótulos dos suplementos alimentares. 


\section{Analytical methods}

All determinations were conducted in triplicates. Moisture content was evaluated according to the standard gravimetric method ${ }^{27}$. $\mathrm{pH}$ was measured by direct readings using a potentiometer (Crison Basic pH 20) fitted with a solid electrode (Crison Electrodes 5011 at room temperature). Water activity (Aw) was determined by direct readings using a water activity meter (HygroLab C1) at $20^{\circ} \mathrm{C}$. Ash content was determined according to standard methods ${ }^{27}$. The same ashes were digested according to Vandecasteele \& Block $(1993)^{28}$ and used for phosphorus, iron, copper, zinc, manganese, sodium, potassium, calcium and magnesium quantification. All minerals, except for phosphorus, were determined by flame atomic absorption spectrophotometry. Phosphorus was quantified by molecular absorption spectrophotometry according to the sodium-ammonium molybdate method. Fibres quantification followed the Van Soeste et al. (1991) ${ }^{29}$ sequential determination method, using the Fibertec system. The calculation sequence was conducted according to Dorleans $(1985)^{30}$, by determination of neutral detergent (NDF) (crude fibre), acid-detergent (ADF) and lignin-acid-detergent (ADL) fibee contents. Crude protein content resulted from total nitrogen determinations using the Kjeldahl method and further calculation using 6.25 as correction factor. The method used for determining gross fat was adapted from IUPAC (1979) ${ }^{31}$. Starting from $5 \mathrm{~g}$ samples, fat was extracted using petroleum ether in a Soxhlet Extractor for 14 hours at $60 \pm 5^{\circ} \mathrm{C}$, followed by 60 minutes drying at $105 \pm 2{ }^{\circ} \mathrm{C}$. Pigments was extracted according to Ramalho et al. (1997) ${ }^{32}$ with modifications. One gram sample was dissolved in $2 \mathrm{~mL}$ of chilled $90 \%$ acetone, bubbled under a gaseous nitrogen stream for 2 minutes and the volume restored to $2 \mathrm{~mL}$ with additional chilled $90 \%$ acetone. After chilling for 30 minutes (protected from light), the sample was centrifuged at $12,000 \mathrm{~g}$ for 10 minutes at $4^{\circ} \mathrm{C}$, and the supernatant was collected and filtered $(0.45 \mu \mathrm{m}$ Nylon Filter VWR). For the determination of total carotenoids an adapted method of Acosta et al. (2009) (33 $^{33}$ was followed and the results were expressed as mg Eq beta-carotene per gram of dry product. Carotenoids profiles were determined by liquid chromatography (HPLC), according to Ramalho et al. $(1997)^{32}$ with modifications. The extracts were injected in a HPLC (Beckman System Gold 126 Solvent Module), equipped with a C18 column (SunFire Waters) $250 \times 4.5 \mathrm{~mm}$, with particle size of $5 \mu \mathrm{m}$ at room temperature. A photo-diodes (DAD) (Beckman System Gold detector 168) detector was used with readings at a wavelength of $440 \mathrm{~nm}$. Eluents were acetonitrile: water (9:1 v:v) containing 10\% triethylamine (A) and ethyl

\section{Determinações Analíticas}

Todas as determinações foram feitas em triplicado. A determinação da humidade da amostra foi realizada de acordo como o método gravimétrico ${ }^{27}$. $\mathrm{O} \mathrm{pH}$ foi medido por leitura direta à temperatura ambiente com recurso a um potenciómetro (Crison Basic $20 \mathrm{pH}$ ) munido de um elétrodo de sólidos (Crison Electrodes 5011). A determinação da aw foi realizada por leitura direta à temperatura de $20^{\circ} \mathrm{C}$ utilizando um medidor de atividade da água (HygroLab C1). O teor de cinza foi determinado de acordo como o método padrão $0^{27}$. A cinza obtida foi digerida de acordo com o método de Vandecasteele \& Block $(1993)^{28}$ para a quantificação da composição em fósforo, ferro, cobre, zinco, manganês, sódio, potássio, cálcio e magnésio. Todos os minerais, com exceção do fósforo, foram determinados através de espectrofotometria de absorção atómica de chama. A determinação do fósforo foi realizada por espectrofotometria de absorção molecular pelo método de Vanadato-Molibdato de Amónio. Para a determinação das fibras utilizou-se o método de determinação sequencial de Van Soeste et al. $(1991)^{29}$, através do sistema Fibertec. O cálculo sequencial destas foi realizado de acordo com Dorleans $(1985)^{30}$, determinando-se o teor das fibras: neutro-detergentes (NDF) (fibra bruta), ácido-detergentes (ADF) e lenhina-ácido detergentes (ADL). A determinação da proteína bruta resultou da determinação do azoto total pelo método de Kjeldahl, multiplicando-se este valor pelo fator de correção de 6,25 . O método utilizado para a determinação da gordura bruta foi adaptado de IUPAC $(1979)^{31}$. Partindo-se de $5 \mathrm{~g}$ de amostra, procedeu-se à extração da gordura com éter de petróleo num extrator de Soxhlet durante 14 horas a $60 \pm 5^{\circ} \mathrm{C}$, seguida de uma secagem durante $1 \mathrm{~h}$ a $105 \pm 2^{\circ} \mathrm{C}$. O método utilizado para a extração dos pigmentos foi adaptado de Ramalho et al. (1997) ${ }^{32}$. Dissolveu-se $1 \mathrm{~g}$ de amostra em $2 \mathrm{~mL}$ de acetona refrigerada a $90 \%$, borbulhou-se sob um fluxo de azoto gasoso durante 2 minutos e completou-se o volume para $2 \mathrm{~mL}$. Após 30 minutos no frio e ao abrigo da luz, a amostra foi centrifugada durante 10 minutos a $4^{\circ} \mathrm{C}$ a $12000 \mathrm{~g}$, o sobrenadante foi recolhido e filtrado (Filtro VWR 0,45 $\mu \mathrm{m}$ Nylon). Para a determinação dos carotenóides totais adaptou-se o método de Acosta et al. (2009) 33 e os resultados foram expressos em mg Eq b-caroteno por grama de produto seco. Para determinar o perfil de carotenóides, recorreu-se a cromatografia líquida de alta eficiência (HPLC), de acordo com Ramalho et al. (1997) ${ }^{32}$ com modificações. Os extratos foram injetados num HPLC (Beckman System Gold 126 Solvent Module), equipado com uma coluna C18 (SunFire Waters) $250 \times 4,5 \mathrm{~mm}$, com tamanho da partícula de 5 $\mu \mathrm{m}$ à temperatura ambiente. $\mathrm{O}$ detetor utilizado foi o fo- 


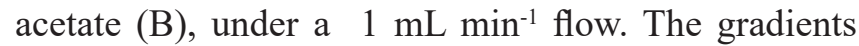
were: 0 to $10: 30$ minutes eluent $\mathrm{B}$ increased from $25 \%$ to $41 \% ; 10: 30 \mathrm{~min}$ to 20 minutes eluent $\mathrm{B}$ increased from $41 \%$ to $100 \%$ and $20: 21$ min eluent B decreased from $100 \%$ to $25 \%$. The results were expressed based on calibration curves prepared with $100 \%$ ethanol-diluted neoxanthin, violaxanthin, antheraxanthin or zeaxanthin solutions of known concentration, 100\% acetone-diluted alpha-carotene, 90\% acetone-diluted beta-carotene or acetonitrile :dichloromethene (1:1 v:v) lycopene. The extracts used for phenolic compounds and antioxidant capacity quantification were obtained using the method described by Swain \& Hillis (1959) ${ }^{34}$. One gram sample was dissolved in $4 \mathrm{~mL}$ absolute methanol, centrifuged at $11,200 \mathrm{~g}$ for 1 minute at $4^{\circ} \mathrm{C}$; and incubated at $4{ }^{\circ} \mathrm{C}$ for 24 hours protected from light. Following the incubation, the solution was centrifuged at 11,200 $\mathrm{g}$ for 8 minutes at $4^{\circ} \mathrm{C}$ and the supernatant was collected and stored at $4{ }^{\circ} \mathrm{C}$ protected from light. Phenolic compounds were quantified also according to Swain \& Hillis (1959) ${ }^{34}$ and the results were expressed as $\mathrm{mg} \mathrm{Eq}$ Gallic acid per gram of dry product. The method used determining antioxidant capacity by DPPH radical capture was adapted from Brand-Williams et al. (1995) ${ }^{35}$ and the results are expressed as mg Eq Trolox per gram of dry product. For the determination of the antioxidant capacity by the ABTS radical (2.2-Azino-bis (3-ethyl benzene-Thiazoline-6-sulphonic acid) capture method, the protocol of Miller et al. (1993) $)^{36}$ was followed and the results were expressed as $\mathrm{mg}$ Eq ascorbic acid per gram of dry product. Vitamin $\mathrm{C}$ was quantified by HPLC (Beckman System Gold 126 Solvent Module), based on Romero-Rao et al. (1992) $)^{37}$ using a C18 column (SunFire Waters) $250 \times 4.5 \mathrm{~mm}$, with particle size of $5 \mu \mathrm{m}$ at room temperature and a diode-array detector (DAD) (Beckman System Gold 168 detector) with readings at $254 \mathrm{~nm}$. The eluent was ultra-purified water acidified with sulfuric acid ( $\mathrm{pH} 2.2)$ and a stream of $0.4 \mathrm{~mL} \mathrm{~min}^{-1}$, during 15 minutes was employed. The determination of vitamin $\mathrm{E}$ was carried out according to Havaux \& Kloppstech $(2001)^{38}$ using a fluorescence detector (Jasco FP 1520), at $290 \mathrm{~nm}$ excitation / 330 $\mathrm{nm}$ emission wavelengths. The eluent used was $100 \%$ methanol under a $1 \mathrm{~mL} \mathrm{~min}^{-1}$ flow, over 20 minutes and the results were expressed as $\alpha$-tocopherol units. Vitamin B1 content was determined by HPLC according to Fernando \& Murphy (1990) ${ }^{39}$. A fluorescence (Jasco FP 1520) detector and wavelengths of $364 \mathrm{~nm}$ (excitation) and $436 \mathrm{~nm}$ (emission) were used. The eluent was 0.01 $\mathrm{M}$ acetonitrile: sodium acetate $(13: 87 \mathrm{v} / \mathrm{v})$ solution at 1

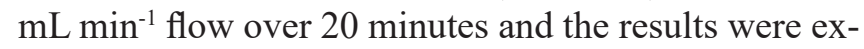
pressed as thiamine. Vitamin B2 was quantified accord- to-diodos (DAD) (Beckman System Gold 168 detetor) e a leitura foi efetuada a um comprimento de onda de 440 $\mathrm{nm}$. Os eluentes utilizados foram acetonitrilo:água (9:1 $\mathrm{v}: \mathrm{v})$ contendo $10 \%$ de trietilamina (A) e acetato de etilo (B) a um fluxo de $1 \mathrm{~mL}$ min-1. Os gradientes utilizados foram: Do 0 aos 10:30 min o eluente B passou de 25\% para $41 \%$; Dos 10:30 min aos 20 min o eluente B passou de $41 \%$ para $100 \%$ e dos 20 aos 21 min o eluente B passou de $100 \%$ para $25 \%$. Os resultados foram expressos com base em curvas de calibração preparadas com soluções de concentração conhecida de Neoxantina diluída em etanol a 100\%, Violaxantina diluída em etanol a $100 \%$, Anteraxantina diluída em etanol a $100 \%$, Luteína diluída em etanol a $100 \%$, Zeaxantina diluída em etanol a $100 \%, \alpha$-caroteno diluído em acetona a $90 \%$, $\beta$-caroteno diluído em acetona a $90 \%$ e Licopeno diluído em acetonitrilo:diclorometeno $(1: 1 \mathrm{v}: \mathrm{v})$. Os extratos utilizados na determinação dos compostos fenólicos e da capacidade antioxidante foram obtidos segundo o método descrito por Swain \& Hillis (1959) adaptado ${ }^{34}$. Pesou-se $1 \mathrm{~g}$ de amostra que se dissolveu em $4 \mathrm{~mL}$ de metanol absoluto, a amostra foi centrifugada durante 1 minuto a $4^{\circ} \mathrm{C}$ a $11200 \mathrm{~g}$ e incubada a $4^{\circ} \mathrm{C}$ durante 24 horas ao abrigo da luz. Seguiu-se nova centrifugação durante 8 minutos a $4^{\circ} \mathrm{C}$ a $11200 \mathrm{~g}$, e o sobrenadante foi recolhido e armazenado a $4^{\circ} \mathrm{C}$ ao abrigo da luz. O método utilizado para quantificação dos compostos fenólicos também seguiu Swain \& Hillis (1959) 34 e os resultados foram expressos em $\mathrm{mg}$ Eq ácido gálico por grama de produto seco. $\mathrm{O}$ método utilizado para a determinação da capacidade antioxidante pela captação do radical DPPH foi adaptado de Brand-Williams et al. $(1995)^{35} \mathrm{e}$ os resultados expressos em mg Eq trolox por grama de produto seco. Para a determinação da capacidade antioxidante pela captação do radical ABTS (2,2- Azino-bis (3-Etilbenzeno- Tiazolina-6- Ácido Sulfónico), foi seguido o protocolo de Miller et al. (1993) ${ }^{36}$, com resultados expressos em $\mathrm{mg}$ Eq ácido ascórbico por grama de produto seco. A determinação da vitamina $\mathrm{C}$ foi realizada por HPLC (Beckman System Gold 126 Solvent Module), com base no método de Romero-Rodrigues et al. (1992) ${ }^{37}$ usando uma coluna C18 (SunFire Waters) 250 $\mathrm{x} 4,5 \mathrm{~mm}$, com tamanho de partícula de $5 \mu \mathrm{m}$ à temperatura ambiente e um detetor de foto-diodos (DAD) (Beckman System Gold 168 detector) com leitura a 254 $\mathrm{nm}$. O eluente utilizado foi água MilliQ acidificada com ácido sulfúrico (pH de 2,2) a um fluxo de $0,4 \mathrm{~mL} \mathrm{min-}$ ${ }^{1}$, durante 15 minutos. A determinação da vitamina $\mathrm{E}$ foi realizada de acordo com o método de Havaux \& Kloppstech $(2001)^{38}$ com detetor de fluorescência (Jasco FP 1520), a um comprimento de onda de excitação de $290 \mathrm{~nm}$ e de emissão de $330 \mathrm{~nm}$. O eluente utilizado 
ing to Fernando \& Murphy $(1990)^{39}$ with fluorescence detection (Jasco FP 1520) using a $436 \mathrm{~nm}$ excitation and $535 \mathrm{~nm}$ emission wavelength. In this determination, samples were eluted in $0.01 \mathrm{M}$ acetonitrile: sodium acetate $(13: 87 \mathrm{v} / \mathrm{v})$ solution at $1 \mathrm{~mL} \mathrm{~min}^{-1}$ flow for 20 minutes. The quantification was completed by comparisons with riboflavin solutions of known concentration. The quantification of vitamins B3, B9 and B12 was performed through microbiological methods adapted from AOAC (1984) $)^{27}$. This method was based on micro-organisms growth as specific correlation factor for the samples' vitamin amounts. Lactobacillus plantarum, Streptococcus faecalis and Lactobacillus delbrueckii were used for the quantification of vitamins B3, B9 and B12, respectively.

\section{Estimation of appropriate daily dose}

The "multimistura" daily dose recommended for each target group (pregnant women, lactating women and children), was estimated taking in account the National Institute of Health ${ }^{40,41}$ Daily Recommended Doses (DRDs). Specifically, the dosage of each individual vitamin and mineral supplied by the recommended daily "multimistura" intake, which was $15 \mathrm{~g}$ for both pregnant or lactating women and $10 \mathrm{~g}$ for children, was investigated.

\section{Compositional comparison with commercial supplements}

The dietary supplement vitamin and mineral content at the recommended daily intake doses was compared to the composition referenced on the labels of dietary commercial supplements targeting the same groups, in their common features, using Multidimensional Scaling (MDS) method ${ }^{42}$. The SPSS software coupled with the Proximity Scaling (PROXSCAL) algorithm, whose initial solution was found by the Simplex Method, was employed in the calculations.

\section{Results and discussion}

\section{Physical-chemical basal characterization}

The investigated dietary supplement was found to have a $5.99 \pm 0.06 \%$ moisture content, which places it under the dehydrated products category ${ }^{43}$. In 2005, the Brazilian Ministry of Health's National Health Surveillance Agency established a maximum of $15 \%$ moisture and volatile substances at $105^{\circ} \mathrm{C}$ to "multimisturas". Since Brazil is the only country that has legislated parameters for this type of product, if this supplement was used in foi metanol a $100 \%$ a um fluxo de $1 \mathrm{~mL} \mathrm{~min}{ }^{-1}$, durante 20 minutos e os resultados expressos em unidades de $\alpha$-tocoferol. A determinação da vitamina B1 foi realizada por HPLC de acordo com o método de Fernando $\&$ Murphy $(1990)^{39}$. O detetor utilizado neste caso foi o de fluorescência (Jasco FP 1520) com um comprimento de onda de excitação de $364 \mathrm{~nm}$ e emissão de $436 \mathrm{~nm}$, o eluente foi acetonitrilo:acetato de sódio 0,01M (13:87 $\mathrm{v} / \mathrm{v}$ ) a um fluxo de $1 \mathrm{~mL}$ min-1, durante 20 minutos e os resultados foram expressos em tiamina. A vitamina B2 foi quantificada de acordo com o método de Fernando \& Murphy (1990) ${ }^{39}$ com deteção de fluorescência (Jasco FP 1520) a comprimento de onda de excitação de $436 \mathrm{~nm}$ e emissão de $535 \mathrm{~nm}$. O eluente utilizado neste caso foi acetonitrilo:acetato de sódio $0,01 \mathrm{M}(13: 87$ $\mathrm{v} / \mathrm{v}$ ) a um fluxo de $1 \mathrm{~mL} \mathrm{~min}^{-1}$ durante 20 minutos. A quantificação foi feita por comparação com soluções de concentração conhecida de riboflavina. A quantificação das vitaminas B3, B9 e B12 foi realizada através de método microbiológico de determinação de vitaminas adaptado de $\mathrm{AOAC}^{27}$. Este método utilizando o crescimento de microrganismos específicos como fator de correlação para a quantidade de vitamina presente na amostra. Os microrganismos Lactobacillus plantarum, Streptococcus faecalis e Lactobacillus delbrueckii foram utilizados na quantificação das vitaminas B3, B9 e $\mathrm{B} 12$, respetivamente.

\section{Estimativa da dose diária adequada}

Para a estimativa da dose diária de multimistura recomendada para cada grupo alvo (grávidas, lactantes e crianças), recorreu-se às DDR's, sugeridas pelo National Institute of Health ${ }^{40,41}$, para as diferentes vitaminas e minerais e averiguou-se que percentagem destas era suprida com a ingestão da multimistura nas doses diárias atualmente recomendadas: $15 \mathrm{~g}$ para grávidas e lactantes e $10 \mathrm{~g}$ para crianças.

\section{Comparação com suplementos alimentares comerciais}

A composição mineral e vitamínica da multimistura, nas doses diárias recomendadas, foi comparada com a composição presente nas doses diárias atualmente recomendadas e referenciadas nos rótulos de suplementos alimentares comerciais direcionados para os mesmos grupos alvo, nos parâmetros comuns, através do Método Multidimensional Scaling (MDS) ${ }^{42}$. Recorreu-se ao programa SPSS com o algoritmo Proximity Scaling (PROXSCAL), cuja solução inicial foi encontrada pelo Método Simplex. 
that country, it would be in accordance with the local legislation obligations ${ }^{44}$. The "multimistura" exhibited a $\mathrm{pH}$ of 4.5, an environment in which few microorganisms are able to grow. In addition, the water activity, calculated to be 0.59 , is considered inhibitory of microbial development. In fact, microbial growth only occurs at Aw values exceeding 0.6 (some fungi and yeasts) and over 0.90 (most bacteria) ${ }^{45}$. The combination of these two factors provides the product with the "stable product" label from the microbial contamination risk perspective. However, one cannot rule out the presence of microorganisms in latent phases, permitting their development under subsequently favorable conditions, in particular, when inside the living organism ${ }^{21}$.

Table 1 displays the chemical composition and caloric value calculated based on $100 \mathrm{~g}$ of dry product. The centesimal composition was shown to be balanced since no macronutrient was quantified as predominant, and all compounds were present in proportions ranging from $20 \%$ to $27 \%$. It was determined that fat was the preponderant macronutrient $(27.17 \%)$. As a product of vegetable origin, a lower lipid content could be expected. Considering the ingredients of this specific "multimistura", this content can be attributed to the pumpkin and sesame seeds, as the lipid levels of the former is ca. $47 \%^{46}$ and the latter is ca. $54 \%{ }^{47}$. An advantage of the high fat content in this scenario is the capacity to promote the absorption of fat-soluble vitamins.

\section{Resultados e Discussão}

\section{Caraterização fisico-química base}

A multimistura apresentou uma humidade de $5,99 \pm 0,06 \%$, o que a enquadra na categoria de produtos desidratados ${ }^{43}$. Em 2005 a Agência Nacional de Vigilância Sanitária do Ministério da Saúde Brasileiro estabeleceu que as multimisturas poderiam apresentar, no máximo, um valor de $15 \%$ de humidade e substâncias voláteis a $105^{\circ} \mathrm{C}$. Sendo o Brasil o único país que tem legislados parâmetros para este tipo de produtos, se este suplemento fosse utilizado no Brasil estaria de acordo com as obrigatoriedades da legislação local ${ }^{44}$. A multimistura apresentou um $\mathrm{pH}$ de 4,5 , valor a que poucos microrganismos são capazes de se desenvolver. Também o valor de aw de 0,59 é inibitório do desenvolvimento microbiano, uma vez que este dá-se em produtos com uma aw superior a 0,6 para alguns fungos e leveduras e superior a 0,90 para a grande maioria das bactérias $^{45}$. A combinação destes dois fatores faz desta multimistura um produto estável sob o ponto de vista microbiano. No entanto, é necessário ter em conta que muitas vezes os microrganismos podem estar presentes mas encontrarem-se em estado latente, o que permite o seu desenvolvimento sob condições favoráveis, nomeadamente no organismo humano ${ }^{21}$.

Table 1/ Tabela 1 - Centesimal Composition (average \pm standard deviation) and caloric value of $100 \mathrm{~g}$ of product (dry product)/ Composição centesimal (média \pm desvio padrão) e valor calórico de $100 \mathrm{~g}$ de produto (base seca)

\begin{tabular}{|c|c|}
\hline Centesimal Composition/ Composição Centesimal & $\%$ \\
\hline Ash/ Cinza & $7,67 \pm 0,10$ \\
\hline Lipids/ Gordura bruta & $27,17 \pm 1,24$ \\
\hline Protein/ Proteína bruta & 20,40 \\
\hline NDF & $24,27 \pm 0,85$ \\
\hline Fibers/ Fibras & $12,90 \pm 0,65$ \\
\hline ADL & $6,01 \pm 0,47$ \\
\hline Carbohydrates*/ Glúcidos* & 20,49 \\
\hline Caloric Value** / Valor calórico & $408,09 \mathrm{Kcal} / 100 \mathrm{~g}$ \\
\hline
\end{tabular}

*Numerical Determination: Carbohydrates $=100-($ Ash + Lipids + Protein + Fibers NDF $) /$ Determinação numérica: Glúcidos $=100-($ Cinza + Gordura bruta + Proteína bruta + Fibra NDF $)$

** Numerical Determination using the Atwater's factors: Lipids= $9 \mathrm{Kcal} / \mathrm{g}$ of product; Protein $=4 \mathrm{Kcal} / \mathrm{g}$ of product; Carbohydrates $=4 \mathrm{Kcal} / \mathrm{g}$ of product/ Determinação numérica usando os fatores de Atwater: Gordura bruta $=9 \mathrm{Kcal} / \mathrm{g}$ de produto; Proteína bruta $=4 \mathrm{Kcal} / \mathrm{g}$ de produto; Glúcidos $=4 \mathrm{Kcal} / \mathrm{g}$ de produto 
The second most abundant macronutrient was fibre (NDF), which featured an expected value of $24.27 \%$. The rice bran, present in the "multimistura" composition, has fibre content of approximately $50 \%{ }^{48}$ and is likely the primary component accountable for the observed content. Carbohydrates were determined to be $20.49 \%$ of the total composition. The ingredient employed that has the highest carbohydrates content is green banana, with reported values of about $91 \%{ }^{49}$. Green bananas are followed by moringa leaves $(44 \%)^{50}$, cassava $(25 \%)^{51}$ and sweet potato $(51 \%)^{52}$. Baobab roots are also recognized as carbohydrate -rich ${ }^{53}$. Theprotein content was quantified at $20.40 \%$, which is considered high for vegetable products. Likewise, this content can be explained by this specific "multimistura" constituents, which include moringa leaves, cassava and sweet potatoes, which are recognized as having protein contents reaching about $29 \%^{50}, 34 \%{ }^{51}$ and $29 \%{ }^{52}$, respectively. Pumpkin seeds, referred previously as being fatrich, also contain high protein value, in the magnitude of $29 \%{ }^{46}$. The ash content was determined to be $7.67 \%$, a high value that suggests a high mineral content.

The caloric value was $408.09 \mathrm{Kcal}$ for $100 \mathrm{~g}$ of dry product, which classifies this product as quite caloric. Comparing this result with the foods listed in the Instituto Nacional de Saúde Dr. Ricardo Jorge's Food Composition Table ${ }^{54}$, the supplement under study is similar to Alverca cured cheese or thin, raw, pork chorizo regarding caloric value.

Globally, the sole compositional negative aspect is the high fibre content that can act as anti-nutritional factor, hindering the absorption of other nutrients by promoting their excretion through feces ${ }^{18}$. Hence, if most of this fibre comes from rice bran, a reduction of this ingredient proportion in the preparation is highly recommended.

\section{Micronutrient composition}

The total carotenoids content was determined as 137.40 $\pm 4.77 \beta$-carotene $\mu \mathrm{g} \mathrm{Eq/g}$ dry weight. Comparing this value with those values obtained for pumpkin, a product recognized as having a high content of carotenoids, the "multimistura" is classified as rich in these compounds. Depending on the variety, pumpkins total carotenoids can range from $18 \mu \mathrm{g} \mathrm{Eq} / \mathrm{g} \beta$-carotene to $230 \mu \mathrm{g} \mathrm{Eq} / \mathrm{g} \beta$-carotene, with average values of 67 $\mu \mathrm{g} \mathrm{Eq} / \mathrm{g} \beta$-carotene ${ }^{55}$. This characteristic provides the dietary supplement with other health benefits. Since carotenoids are phytochemical, biologically active compounds, they may act as antioxidant, anticancer, antimicrobial, anti-inflammatory and antithrombotic molecules ${ }^{25}$. The carotenoids investigated included
Na tabela 1 apresenta-se a composição centesimal e o valor calórico para $100 \mathrm{~g}$ de produto seco. Como é possível verificar, a composição centesimal da multimistura é equilibrada uma vez que nenhum dos macronutrientes é dominante, estando todos presentes em proporções entre $20 \%$ e $27 \%$. Verificou-se que a gordura bruta foi o macronutriente com maior peso $(27,17 \%)$. Tratando-se de um produto de origem vegetal, poder-se-iam esperar um teor de lípidos mais baixos, mas olhando para a composição desta multimistura em particular, este resultado pode ser atribuído à presença das sementes de abóbora e de sésamo, sendo que as primeiras tem teores lipídicos na ordem dos $47 \%{ }^{46}$ e as segundas na ordem dos $54 \%{ }^{47}$. Uma vantagem do elevado teor de gordura apresentado por este produto é a promoção da absorção das vitaminas lipossolúveis. O segundo macronutriente que se apresenta em maior quantidade na multimistura é a fibra (NDF), que apresentou um valor espectável de $24,27 \%$. O farelo de arroz, presente na multimistura, com um teor de fibra aproximadamente de $50 \%{ }^{48}$, será provavelmente o responsável pelo valor obtido. Os glúcidos, que foram determinados numericamente, correspondem a $20,49 \%$ da composição da multimistura. O componente da multimistura que apresenta o maior teor de glúcidos é a banana verde, em valores de cerca de $91 \%{ }^{49}$, seguindo-se as folhas de moringa $(44 \%)^{50}$, de mandioca $(25 \%)^{51}$ e de batata-doce $(51 \%)^{52}$. A raiz do embondeiro é também reconhecida como sendo rica em glúcidos ${ }^{53}$. A multimistura apresentou um teor de proteína de $20,40 \%$, que é considerado elevado para um produto de origem vegetal. Mais uma vez pode ser explicado pelos constituintes da multimistura em estudo, que contém folhas de moringa, de mandioca e de batata-doce. Estes produtos vegetais são reconhecidos como tendo um teor proteico de aproximadamente $29 \%{ }^{50}, 34 \%{ }^{51}$ e $29 \%{ }^{52}$, respetivamente. As sementes de abóbora, referidas anteriormente como sendo ricas em gordura, também contêm um elevado valor proteico, na ordem dos $29 \%{ }^{46}$. O teor de cinza da multimistura foi de 7,67\%; um valor elevado que sugere que a multimistura apresenta um elevado teor em minerais.

A multimistura apresentou o valor calórico de 408,09 Kcal para $100 \mathrm{~g}$ de produto seco, o que a classifica como um produto bastante calórico. Comparando este resultado como os produtos da Tabela de Composição de Alimentos do Instituto Nacional de Saúde Doutor Ricardo Jorge ${ }^{54}$, a multimistura apresentou o mesmo valor calórico que o Queijo Alverca curado ou que o Chouriço de carne de porco, magro, cru.

De um modo geral, o único aspeto negativo que a multimistura apresenta, do ponto de vista da composição, é o elevado teor de fibras, que podem atuar como fatores 


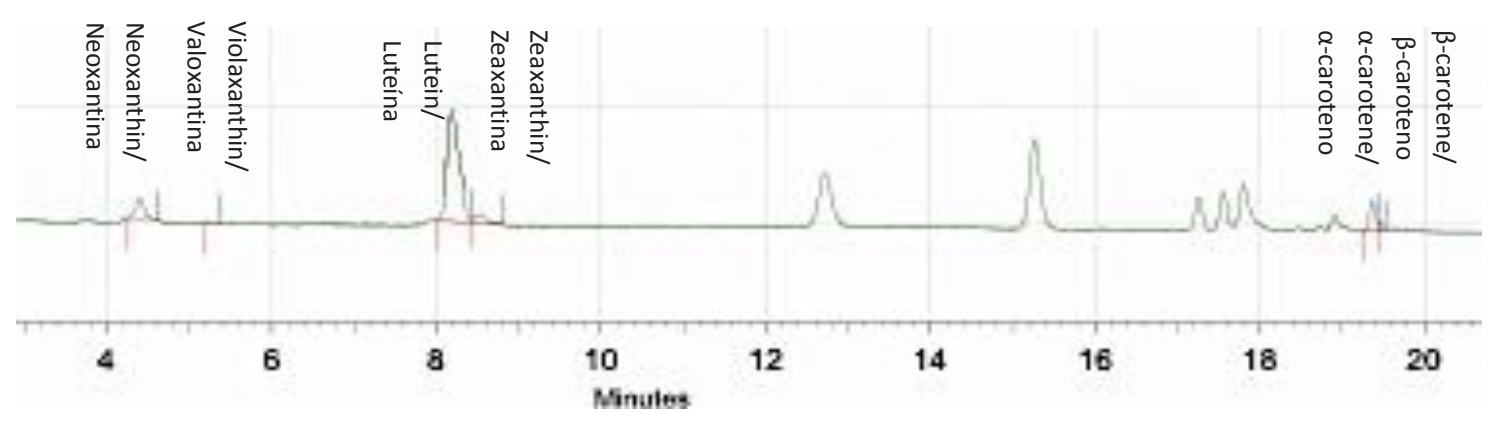

Figure 2/ Figura 2 - Carotenoids profile chromatogram

Cromatograma do perfil de carotenóides da multimistura.

neoxanthin, antheraxanthin, violaxanthin, lutein, zeaxanthin, lycopene, $\alpha$-carotene and $\beta$-carotene. The carotenoids profile chromatogram is shown in Figure 2, and indicates the values of antheraxanthin and lycopene to be below the detection limit, since the corresponding peaks should have been observed at 6.3 and 18.1 minutes, respectively. Table 2 displays the content the individual carotenoids quantified. The most abundant carotenoid - lutein - was quantified at $7.28 \mathrm{mg} / 100 \mathrm{~g}$ dry weight. The remaining carotenoids are present in amounts ranging from $0.11 \mathrm{mg}$ to $0.95 \mathrm{mg} / 100 \mathrm{~g}$ of dry weight (Table 2). Comparing the "multimistura""s carotenoids profile with that of spinach, a product known to be carotenoid-rich, one can suggest that the "multimistura" lutein content is quite high, although the content of the remaining carotenoids is considered as low. In spinach, the carotenoids profile is dominated by $\beta$-carotene, lutein and neoxanthin, with $8.3 \mathrm{mg} / 100$ $\mathrm{g}, 7.6 \mathrm{mg} / 100 \mathrm{~g}$ and $2.5 \mathrm{mg} / 100 \mathrm{~g}$, respectively ${ }^{56}$. The high lutein content brings additional health benefits due to its known antioxidant properties and for its role in preventing ophthalmology damages ${ }^{57}$. The observed low levels of both $\alpha$-carotene and $\beta$-carotene stand as a negative feature of the global carotenoid profile. Since these molecules are the precursors of vitamin A synthesis, a low content of this vitamin can be suggested. Although with a high total carotenoid content, only six individual carotenoids have been identified in the "multimistura", of which only lutein was detected in high levels. This observation suggests that the amount of total carotenoids quantified results from less commonly considered molecules from this family.

The product investigated showed also a relatively high antinutricionais, dificultando a absorção dos restantes nutriente promovendo a sua excreção pelas fezes ${ }^{18}$. Assim, e se a maioria da fibra presente na multimistura for resultante da presença do farelo de arroz, recomenda-se que se reduza a proporção deste ingrediente na sua elaboração.

\section{Composição em micronutrientes}

O teor de carotenóides totais determinado para a multimistura foi de 137,40 $\pm 4,77 \mu \mathrm{g} \mathrm{Eq} \beta$-caroteno/g produto seco. Comparando este valor com valores obtidos para a abóbora, um produto reconhecido como tendo um elevado teor de carotenóides, a multimistura classifica-se como rica nestes compostos. Consoante a variedade, a abóbora pode apresentar valores de carotenóides totais entre $18 \mu \mathrm{g}$ Eq $\beta$-caroteno/g e $230 \mu \mathrm{g} \mathrm{Eq} \beta$-caroteno/g, com valores médios de $67 \mu \mathrm{g}$ Eq $\beta$-caroteno/g55. Devido à presença destes compostos, a multimistura apresenta outros benefícios para saúde para além do aspeto nutricional. Dado que os carotenóides são compostos fitoquímicos, biologicamente ativos, poderão exercer no organismo efeitos antioxidante, anticancerígeno, antimicrobiano, antiinflamatório e antitrombótico ${ }^{25}$. Os carotenóides investigados foram a neoxantina, a violaxantina, a anteraxantina, a luteína, a zeaxantina, o licopeno, o $\alpha$-caroteno e o $\beta$-caroteno. $O$ cromatograma do perfil de carotenóides obtido para a multimistura encontra-se representado na Figura 2, e mostra que a anteraxantina e o licopeno apresentam-se em valores abaixo do limite de deteção, já que os picos correspondentes deveriam ter surgido ao minuto 6,3 e 18,1, respetivamente. A Tabela 2 mostra o teor de cada um dos carotenóides presentes. O carotenóide mais abun- 
Table 2/ Tabela 2 - Content of carotenoids identified (average \pm standard deviation) in $100 \mathrm{~g}$ of product (dry product)/ Teor de carotenóides identificados (média \pm desvio padrão) em 100 g multimistura (base seca)

\begin{tabular}{cc}
\hline Carotenoids/ Carotenóides & $\mathbf{m g} / \mathbf{1 0 0} \mathbf{g}$ \\
\hline Neoxanthin/ Neoxantina & $0,52 \pm 0,04$ \\
Violaxanthin/ Violaxantina & $0,11 \pm 0,004$ \\
Lutein/ Luteína & $7,28 \pm 0,12$ \\
Zeaxanthin/ Zeaxantina & $0,43 \pm 0,06$ \\
$\boldsymbol{\alpha}$-carotene/ $\boldsymbol{\alpha}$-caroteno & $0,95 \pm 0,05$ \\
$\boldsymbol{\beta}$-carotene/ $\boldsymbol{\beta}$-caroteno & $0,22 \pm 0,03$ \\
\hline
\end{tabular}

phenolic compound content of $2.41 \pm 0.06 \mathrm{mg}$ Eq Gallic acid /g dry weight. This content is higher than that reported for plums, a fruit regarded as phenolic compounds-rich (depending on the variety), ranging from 0.62 to $2.09 \mathrm{mg}$ Eq Gallic acid $\mathrm{mg} / \mathrm{g}$ dry weight ${ }^{58}$. The antioxidant capacity assessed by DPPH and ABTS methods indicated very high levels and a strong agreement between both methods (Table 3 ). This result was expected considering the "multimistura"s phenolic and carotenoid content. The antioxidant capacity is similar to green tea, in which $1.85 \mathrm{mg}$ Eq Ascorbic acid /g was reported after ABTS quantification, which ranks green tea in eighth position in a list of ten foods recognized as having the highest known antioxidant capacity ${ }^{59}$. Therefore, including the "multimistura" in the diet brings additional health benefits beyond its main purpose in fighting nutritional deficiency.

Regarding its mineral content, the product was characterised as poor in copper, manganese and sodium, balanced in potassium and calcium, and rich in phosphorus, iron, zinc and magnesium (Table 4). To gain a further insight on whether the levels of each mineral are high or low, the putative nutrition claim that could be declared according to European legislation was investigated. To that end, the EC Regulation No. 1924/2006 (2006) ${ }^{60}$ was followed. According to this document, a food can be considered rich in a micronutrient if $100 \mathrm{~g}$ are able to deliver $\geq 30 \%$ of the DRD, a source if 100 $\mathrm{g}$ of the product meets $15 \%-30 \%$ of the DRD, or has no nutrition claim if $100 \mathrm{~g}$ of the product meet less than $15 \%$ of the DRD in that specific micronutrient.

The amount of phosphorus $(1019 \mathrm{mg} / 100 \mathrm{~g})$ is quite high as, according to the European legislation, the "multimistura" would be considered as phosphorusrich. Likewise, iron is quantified at $17.44 \mathrm{mg} / 100 \mathrm{~g}$ dante foi a luteína, estando presente na proporção de $7,28 \mathrm{mg} / 100 \mathrm{~g}$ de produto seco. Os restantes carotenóides encontram-se presentes em quantidades entre 0,11 $\mathrm{mg} / 100 \mathrm{~g}$ e $0,95 \mathrm{mg} / 100 \mathrm{~g}$ de produto seco (Tabela 2). Comparando o perfil de carotenóides obtido para a multimistura com o do espinafre, produto conhecido por apresentar elevados teores destas substâncias, concluímos que o teor de luteína presente na multimistura é bastante elevado, embora o teor dos restantes carotenóides seja baixo. No espinafre, o perfil de carotenóides é dominado pelo $\beta$-caroteno, luteína e neoxantina, nas quantidades de $8,3 \mathrm{mg} / 100 \mathrm{~g}, 7,6 \mathrm{mg} / 100 \mathrm{~g}$ e 2,5 $\mathrm{mg} / 100 \mathrm{~g}$, respetivamente ${ }^{56}$. O elevado teor de luteína traz benefícios para a saúde, devido às suas conhecidas propriedades antioxidantes e por prevenir problemas de visão ${ }^{57}$. Os baixos teores de $\alpha$-caroteno e $\beta$-caroteno são um aspeto negativo do perfil de carotenóides observado. Sendo estas substâncias os percursores de vitamina A, este é um indicador do baixo teor desta vitamina. De salientar que embora a multimistura tenha apresentado em elevado teor de carotenóides totais, somente 6 carotenóides foram identificados, e dos quais apenas a luteína apresentou um teor elevado. Esta observação sugere que a quantidade de carotenóides totais presentes na multimistura deve-se a compostos menos comuns desta família.

A multimistura apresentou um teor relativamente ele-

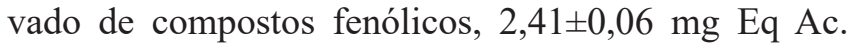
Gálico/g produto seco, valor superior ao da ameixa, fruto considerado como rico em compostos fenólicos com teores (consoante a variedade) entre $0,62 \mathrm{mg} \mathrm{Eq}$ Ac. Gálico/g e 2,09 mg Eq Ac. Gálico/g ${ }^{58}$. A capacidade antioxidante da multimistura determinada pelos métodos DPPH e ABTS revelou concordância entre métodos e teores bastante elevados (Tabela 3), como seria 
Table 3/ Tabela 3 - Antioxidant Capacity (average \pm standard deviation) of the product (dry product) Capacidade antioxidante (média \pm desvio padrão) da multimistura pelo método DPPH e ABTS (base seca).

\begin{tabular}{ll}
\hline Methods/ Métodos & \\
\hline DPPH & $1,84 \pm 0,01 \mathrm{mg} \mathrm{Eq} \mathrm{Trolox} / \mathrm{g}$ \\
ABTS & $1,86 \pm 0,07 \mathrm{mg} \mathrm{Eq}$ Ascorbic acid/ ácido Ascórbico /g \\
\hline
\end{tabular}

Table 4/ Tabela 4 - Mineral Composition (average \pm standard deviation) of $100 \mathrm{~g}$ of product (dry product) and the putative nutrition claim that could be declared according to European legislation

Composição mineral (média \pm desvio padrão) em 100 g multimistura (base seca) e tipo de alegação nutricional que poderia ser feita tendo em conta o teor de cada mineral na multimistura de acordo com a legislação europeia.

\begin{tabular}{|c|c|c|}
\hline $\begin{array}{l}\text { Mineral / } \\
\text { Minerais }\end{array}$ & $\mathrm{mg} / 100 \mathrm{~g}$ & $\begin{array}{l}\text { Putative nutrition claim that could be declared according } \\
\text { to European legislation } \\
\text { (EC Regulation No. 1924/2006) } \text { ( }^{60}\end{array}$ \\
\hline $\begin{array}{l}\text { Phosphorus/ } \\
\text { Fósforo }\end{array}$ & $1019,23 \pm 58,98$ & $\begin{array}{l}\text { Rich/ } \\
\text { Produto rico }\end{array}$ \\
\hline Iron/ Ferro & $17,44 \pm 2,00$ & Rich/ Produto rico \\
\hline Copper/ Cobre & $0,009 \pm 0,001$ & $\begin{array}{l}\text { No Nutrition Claim/ Nenhuma alegação nutricional pode se } \\
\text { feita }\end{array}$ \\
\hline Zinc/ Zinco & $13,32 \pm 0,65$ & Rich/ Produto rico \\
\hline $\begin{array}{l}\text { Manganese/ } \\
\text { Manganês }\end{array}$ & $0,05 \pm 0,01$ & $\begin{array}{l}\text { No Nutrition Claim/ Nenhuma alegação nutricional pode ser } \\
\text { feita }\end{array}$ \\
\hline Sodium/ Sódio & $58,43 \pm 23,96$ & $\begin{array}{l}\text { No Nutrition Claim/ Nenhuma alegação nutricional ode ser } \\
\text { feita }\end{array}$ \\
\hline $\begin{array}{l}\text { Potassium/ } \\
\text { Potássio }\end{array}$ & $1201,50 \pm 186,11$ & $\begin{array}{l}\text { Source/ } \\
\text { Produto fonte }\end{array}$ \\
\hline Calcium/ Cácio & $183,33 \pm 8,66$ & Source/ Produto fonte \\
\hline $\begin{array}{l}\text { Magnesium/ } \\
\text { magnésio }\end{array}$ & $626,25 \pm 7,46$ & $\begin{array}{l}\text { Rich/ } \\
\text { Produto rico }\end{array}$ \\
\hline
\end{tabular}

levels, meaning and it also can be considered as an iron-rich product. These observations are in accordance with the main purpose of this supplement, which was designed to meet, at least partially, the micronutrient needs of the Mozambique population which is known to lack iron intake ${ }^{17}$. Copper was quantified in low values, reaching only $0.009 \mathrm{mg} / 100 \mathrm{~g}$, for which no nutrition claim could be made. Conversely, zinc was observed in high amounts (13.32 mg/100 g). Similarly to iron, zinc is also commonly in deficit for most of the Mozambican population ${ }^{17}$ and the amount detected supports the "multimistura" function as, according to European legislation, it can be declared as zinc-rich product. Manganese was present at an extremely low content of $0.05 \mathrm{mg} / 100 \mathrm{~g}$, meaning that that no nutrition claim could be declared. The $58.43 \mathrm{mg} / 100 \mathrm{~g}$ sodium content is also insufficient to allow declaring any nutrition claim. The "multimistura" was found to have a potas- espetável, face aos valores de compostos fenólicos e carotenóides previamente determinados. A capacidade antioxidante da multimistura é semelhante à capacidade antioxidante do chá verde. Quando quantificado pelo método ABTS, o chá verde apresenta um poder antioxidante de 1,85 mg Eq Ac. Ascórbico/g, encontrando-se em $8^{\circ}$ lugar numa lista dos dez produtos alimentares reconhecidos como tendo o maior poder antioxidante ${ }^{59}$. Assim, confirma-se que a inclusão da multimistura na dieta trás benefícios para a saúde para além do seu principal objetivo, combater a deficiência nutricional.

Atendendo à totalidade dos minerais quantificados, a multimistura apresentou-se pobre em cobre, manganês e sódio, equilibrada em potássio e cálcio e rica em fósforo, ferro, zinco e magnésio (Tabela 4). Para entender se os teores de cada mineral na multimistura são elevados ou reduzidos, averiguou-se que tipo de alegação nutricional poderia ser feita tendo em conta o teor de cada mineral na multimistura, de acordo com a legis- 
sium content of $1,201.50 \mathrm{mg} / 100 \mathrm{~g}$, which, according to the European legislation, characterises it as a source of this mineral. In order to considered rich, the product would need a minimum of $1,410.00 \mathrm{mg} / 100 \mathrm{~g}$. Calcium was present at $183.33 \mathrm{mg} / 100 \mathrm{~g}$ hence, similarly to potassium, places the "multimistura" in the "source of calcium" list, according to European legislation. In fact, at least $240.00 \mathrm{mg} / 100 \mathrm{~g}$ were needed for the product could be considered calcium-rich. Since calcium is one of the micronutrients most commonly lacking in a large proportion of the country's population, revisiting the ingredients to incorporate a calcium-rich element is strongly suggested. Among possible recommendations, the incorporation of eggshell stands as a good alternative, due to its classification as a by-product and availability in the region. Previous studies have shown that after eggshell incorporation, "multimisturas" become significantly increased in this micronutrient, contributing in a relevant way to the proper intake of this mineral $^{26}$. lação europeia, seguindo-se para este efeito o Regulamento CE No $1924 / 2006^{60}$. Assim, um alimento pode ser considerado: RICO num micronutriente, se $100 \mathrm{~g}$ de produto suprirem $\geq 30 \%$ da DDR desse mesmo micronutriente; FONTE, se $100 \mathrm{~g}$ de produto suprirem $\geq 15 \%$ e $<30 \%$ da DDR; ou NENHUMA ALEGAÇÃO NUTRICIONAL, se $100 \mathrm{~g}$ de produto suprirem $<15 \%$ da DDR.

A quantidade de fósforo presente na multimistura (1019 $\mathrm{mg} / 100 \mathrm{~g}$ ) é bastante elevada. Segundo a legislação europeia, a multimistura seria considerada como um produto rico em fósforo. $\mathrm{O}$ ferro encontra-se presente na quantidade de $17,44 \mathrm{mg} / 100 \mathrm{~g}$, e com este resultado a multimistura também pode ser considerada como um produto rico em ferro.

Este resultado está em conformidade com o objetivo do suplemento, pois o intuito da multimistura é o de suprir, em parte, as necessidades em micronutrientes da população moçambicana e um dos micronutrientes que se encontra mais comummente em défice é o ferro ${ }^{17}$.

Table 5/ Tabela 5 - Vitamin Composition (average \pm standard deviation) of $100 \mathrm{~g}$ of product (dry product) and the putative nutrition claim that could be declared according to European legislation/ Componente vitamínica (média \pm desvio padrão) em $100 \mathrm{~g}$ multimistura (base seca) e tipo de alegação nutricional que poderia ser feita tendo em conta o teor de cada vitamina na multimistura de acordo com a legislação europeia.

\begin{tabular}{|c|c|c|}
\hline Vitamin/ Minerais & $\mathrm{mg} / 100 \mathrm{~g}$ & $\begin{array}{l}\text { Putative nutrition claim that could be declared } \\
\text { according to European legislation } \\
{\text { (EC Regulation No. } 1924 / 2006)^{60}}^{6}\end{array}$ \\
\hline $\begin{array}{l}\text { Vitamin } A^{* /} \\
\text { Vitamina } A^{*}\end{array}$ & $0,06 \pm 1,06 \times 10^{-5 * *}$ & $\begin{array}{l}\text { No Nutrition Claim/ Nenhuma alegação nutricional pode } \\
\text { ser feita }\end{array}$ \\
\hline $\begin{array}{l}\text { Vitamin } B_{1} / \\
\text { Vitamina } B_{1}\end{array}$ & $0,61 \pm 0,05$ & $\begin{array}{l}\text { Rich/ } \\
\text { Produto rico }\end{array}$ \\
\hline $\begin{array}{l}\text { Vitamin } B_{2} / \\
\text { Vitamina } B_{2}\end{array}$ & $11,17 \pm 0,65$ & $\begin{array}{l}\text { Rich/ } \\
\text { Produto rico }\end{array}$ \\
\hline $\begin{array}{l}\text { Vitamin } B_{3} / \\
\text { Vitamina } B_{3}\end{array}$ & $26,59 \pm 3,19$ & $\begin{array}{l}\text { Rich/ } \\
\text { Produto rico }\end{array}$ \\
\hline $\begin{array}{l}\text { Vitamin } B_{9} / \\
\text { Vitamina } B_{9}\end{array}$ & $0,12 \pm 0,01$ & $\begin{array}{l}\text { Rich/ } \\
\text { Produto rico }\end{array}$ \\
\hline $\begin{array}{l}\text { Vitamin } B_{12} / \\
\text { Vitamina } B_{12}\end{array}$ & $0,0007 \pm 0,0001$ & $\begin{array}{l}\text { Rich/ } \\
\text { Produto rico }\end{array}$ \\
\hline $\begin{array}{l}\text { Vitamin C/ } \\
\text { Vitamina C }\end{array}$ & $8,16 \pm 0,11$ & $\begin{array}{l}\text { No Nutrition Claim/ / Nenhuma alegação nutricional } \\
\text { pode ser feita }\end{array}$ \\
\hline $\begin{array}{l}\text { Vitamin E/ } \\
\text { Vitamina E }\end{array}$ & $19,53 \pm 0,68$ & $\begin{array}{l}\text { Rich/ } \\
\text { Produto rico }\end{array}$ \\
\hline
\end{tabular}

\footnotetext{
* Numerical Determination: vitamin $\mathrm{A}=(\alpha$-carotene/24 $)+(\beta$-carotene/12)62/ *Determinação numérica: vitamina $\mathrm{A}=$ $(\alpha$-caroteno/24) $+(\beta$-caroteno/12) $(\mathrm{NIH}$, s.d. c).62

** Standard Deviation by the error propagation formula: $\operatorname{SD}($ vitamin $\mathrm{A})=\sqrt{ }\{[(1 / 24) 2 \cdot \operatorname{SD}(\alpha$-carotene $) 2]+[(1 / 12) 2$. $\mathrm{SD}(\beta$-carotene $) 2]\} / * *$ Desvio padrão pela fórmula de propagação de erro: $\operatorname{DP}($ vitamina $\mathrm{A})=\sqrt{ }\{[(1 / 24) 2 \operatorname{DP}(\alpha-$ caroteno $) 2]+[(1 / 12) 2 . \mathrm{DP}(\beta$-caroteno $) 2]\}$.
} 
The amount of magnesium detected was extremely high $(625.25 \mathrm{mg} / 100 \mathrm{~g})$, placing the supplement in the magnesium-rich classification. Nonetheless, the amount may be disadvantageous, as it is known to compete with other minerals in the mucous membrane, preventing their absorption ${ }^{61}$. Cassava leaves, with reported $320.00 \mathrm{mg} / 100 \mathrm{~g}$, can be the ingredient responsible for this high magnesium delivery ${ }^{51}$. Hence, we recommend a reassessment of the cassava percentage in the product formulation.

The "multimistura" vitamin composition is listed in Table 5. Similarly to the mineral component, vitamin contents were compared to the EC Regulation (EC) No. $1924 / 2006,2006^{60}$. Considering the total vitamin quantification, the supplement was shown to be poor in vitamins $\mathrm{A}$ and $\mathrm{C}$ and rich in vitamin $\mathrm{B} 1, \mathrm{~B} 2, \mathrm{~B} 3$, B9, B12 and E. The $0.06 \mathrm{mg} / 100 \mathrm{~g}$ vitamin A content was quite low, meaning that no nutrition claim could be made. At least a $0.12 \mathrm{mg} / 100 \mathrm{~g}$ content was needed for classification as source of vitamin A. Since vitamin A is very commonly in deficit among the Mozambican population $^{17}$, it would be advisable to incorporate an ingredient rich in this micronutrient, such as mango, which is abundant in the country. Vitamin B1 (thiamin) was quantified in a quantity of $0.61 \mathrm{mg} / 100 \mathrm{~g}$, which allows for a vitamin B1-rich classification. It also was determined that the vitamin B2 (riboflavin) amount was extremely high $(11.17 \mathrm{mg} / 100 \mathrm{~g})$. Thus, the product is also considered rich in this vitamin, following the European legislation text. Likewise, vitamin B3 (niacin) was extremely abundant (26.79 mg/100 g) and a "rich" classification can be attributed according to the European legislation. Niacin is known to lack in the Mozambique diet ${ }^{17}$, so this result is very satisfactory. Vitamins B9 (folic acid) and B12 (cobalamin) were quantified in $0.12 \mathrm{mg} / 100 \mathrm{~g}$ and $0.0007 \mathrm{mg} / 100 \mathrm{~g}$ proportions, respectively. These values are high, placing the "multimistura" in the "rich" list of products. A $8.16 \mathrm{mg} / 100$ $\mathrm{g}$ content of vitamin $\mathrm{C}$ (ascorbic acid) was measured, meaning that this vitamin amount is so low that no nutrition claim could be declared. Vitamin E (tocopherol) is present in amounts of $19.53 \mathrm{mg} / 100 \mathrm{~g}$, allowing the classification of the product as vitamin E-rich. This vitamin $\mathrm{E}$ is also one of the most limiting elements for a good health in Mozambican ${ }^{17}$, and the "multimistura" was shown to help fulfill this need, according to its proposed goal.

\section{Estimates of appropriate daily doses}

Figure 3 shows the percentage of the Recommended Daily Intake (RDI) both supplied and lacking of each micronutrient, if considering the "multimistura" daily
O cobre apresentou-se em valores baixos, encontrando-se presente na quantidade de $0,009 \mathrm{mg} / 100 \mathrm{~g}$, pelo que nenhuma alegação nutricional poderia ser feita relativamente à quantidade deste elemento na multimistura. Por outro lado, a quantidade de zinco foi bastante elevada $(13,32 \mathrm{mg} / 100 \mathrm{~g})$. Tal como o ferro, o zinco também é um dos micronutrientes que se encontra mais comummente em défice na população moçambicana ${ }^{17}$. Assim, esta quantidade de zinco respeita os objetivos da multimistura, já que esta seria considerada como um produto rico em zinco, segundo a legislação europeia. $\mathrm{O}$ manganês apresentou um teor extremamente baixo, quantificado em $0,05 \mathrm{mg} / 100 \mathrm{~g}$ assim, sendo que nenhuma alegação nutricional poderia ser feita. O sódio encontra-se presente em valores de $58,43 \mathrm{mg} / 100$ g. Também para este elemento seria necessário uma maior quantidade para se poder fazer alegação nutricional. A multimistura apresentou um teor de potássio de $1201,50 \mathrm{mg} / 100 \mathrm{~g}$, o que segundo a legislação europeia, a consideraria como uma "fonte" de potássio. Para ser considerada um produto rico necessitaria de ter na sua constituição um mínimo de $1410,00 \mathrm{mg} / 100 \mathrm{~g}$. O cálcio encontra-se presente na quantidade de 183,33 mg/100 g. Tal como o potássio, esta quantidade não é suficiente para, de acordo com a legislação europeia, a multimistura ser considerada um produto rico em cálcio (necessitava no mínimo de 240,00 mg/100 g), mas a multimistura pode ser considerada fonte de cálcio. Sendo o cálcio um dos micronutrientes que mais comummente se apresenta em défice na população moçambicana, seria benéfico rever a composição da multimistura para se incorporar um alimento rico em cálcio. Uma recomendação seria a incorporação de casca de ovo. Estudos demostram que a incorporação deste produto, de relativa disponibilidade e considerado um subproduto, nas multimisturas aumenta consideravelmente o teor deste micronutriente, contribuindo de forma relevante para a ingestão adequada deste mineral ${ }^{26}$. A quantidade de magnésio determinada foi extremamente elevada $(625,25 \mathrm{mg} / 100 \mathrm{~g})$, tornando a multimistura um produto considerado rico em magnésio. A quantidade deste mineral poderá apresentar-se como desvantajosa, uma vez que este compete com os restantes minerais na mucosa, impedindo a absorção dos mesmos ${ }^{61}$. Um dos ingredientes da multimistura que presumivelmente contém um elevado ter de magnésio é a folha de mandioca $(320,00 \mathrm{mg} / 100 \mathrm{~g})^{51}$, sendo recomendável reavaliar a sua quantidade na produção deste produto.

A componente vitamínica da multimistura encontra-se listada na Tabela 5. Tal como para a componente mineral, também para a componente vitamínica foram comparados os teores de vitaminas com o Regulamento 

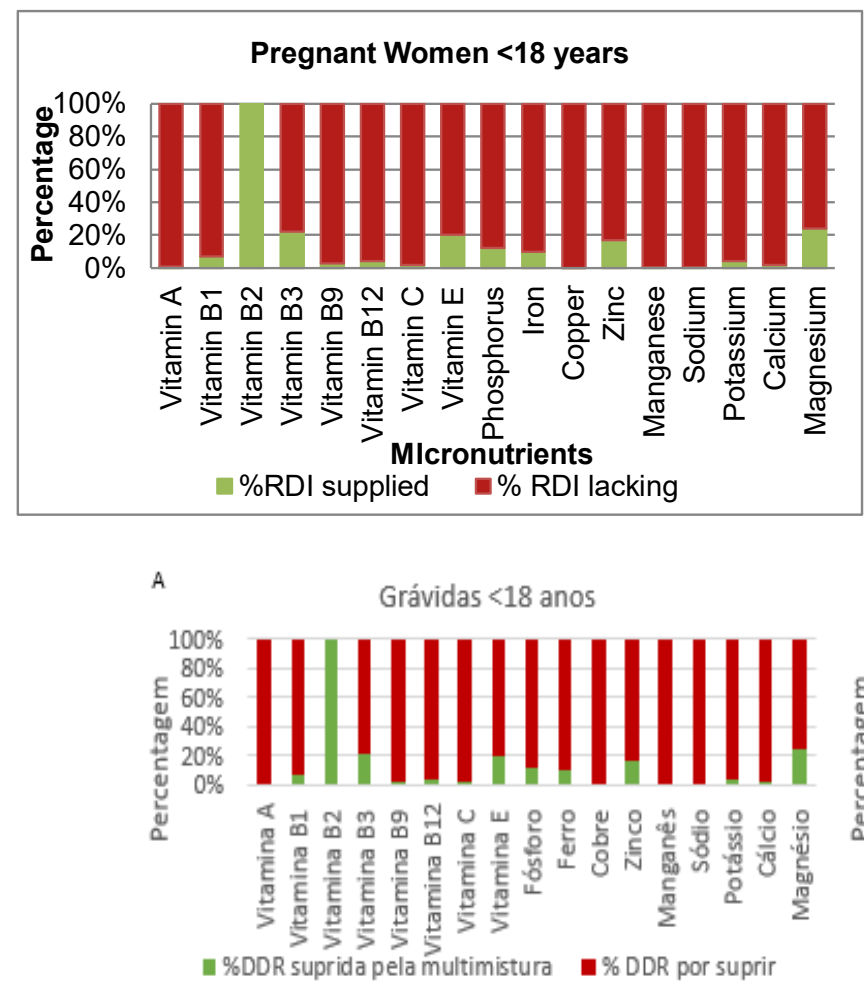

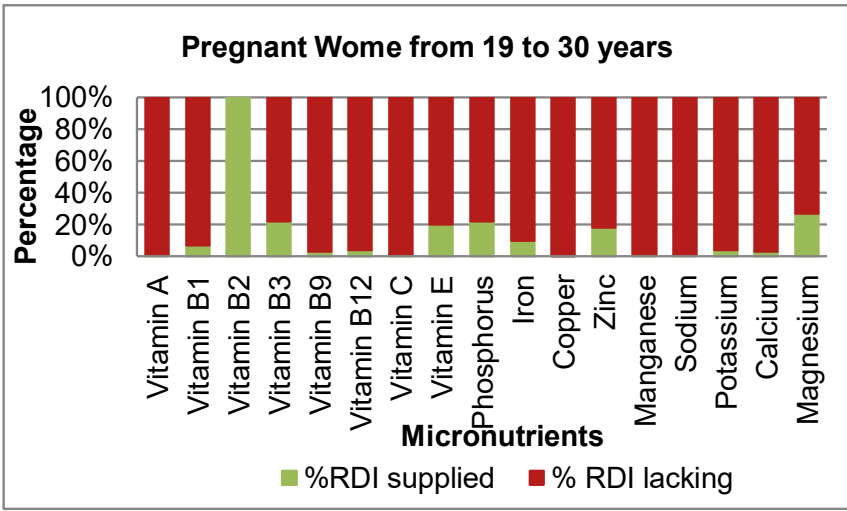

B

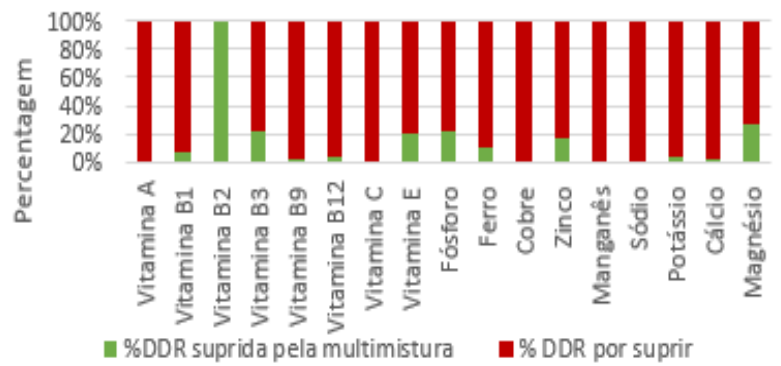

Figure 3/ Figura 3 - Percentage of the RDI supplied and lacking in pregnant women from 19 to 30 years (A) and $<18$ years (B) with the ingestion of the multimistura

Percentagem da DDR dos micronutrientes, supridas e por suprir com a ingestão da multimistura para grávidas com $<18$ anos $(\mathrm{A})$ e grávidas entre 19 a 30 anos (B).

doses currently recommended by the religious congregation: $15 \mathrm{~g}$ for pregnant women under the age of 18 years old and for pregnant women between 19 and 30 years old. The results show no differences between the two age segments. The only difference regarding the RDI percentage supplied with the intake, which is $12 \%$ in pregnant women under 18 years old and $22 \%$ between 19 and 30 years old. In general, the $15 \mathrm{~g}$ amount ingested daily by pregnant women does not guarantee a good RDI proportion for the micronutrients analyzed. In fact, all percentages are lower than $30 \%$ of the RDI, with the exception of vitamin B2. The daily dose ingested leads to exceeding this vitamin's RDI by $20 \%$. Among the micronutrients supplied in a larger RDI percentage (although not reaching adequate levels) are: vitamin B3 (22\% for both groups), vitamin E (20\% for both groups), phosphorus (12\% for pregnant women with less than 18 years old; $22 \%$ for pregnant women between 19 and30 years old), iron (10\% for both groups), zinc (17\% for younger pregnant and $18 \%$ for the 19 to 30 year old group) and magnesium (24\% for pregnant women under 18 years old and $27 \%$ for preg-
CE $\mathrm{N}^{\circ} 1924 / 2006^{60}, 2006$. Atendendo à totalidade das vitaminas quantificadas, a multimistura apresentou-se pobre nas vitaminas $\mathrm{A}$ e $\mathrm{C}$ e rica em vitamina $\mathrm{B} 1, \mathrm{~B} 2$, B3, B9, B12, e E. De fato, a multimistura apresentou um teor de vitamina A de $0,06 \mathrm{mg} / 100 \mathrm{~g}$, que é bastante baixo e de acordo com o qual nenhuma alegação nutricional poderia ser feita. Para tal acontecer a multimistura teria de apresentar no mínimo $0,12 \mathrm{mg} / 100 \mathrm{~g}$. Sendo que a vitamina A apresenta-se muito comummente em défice na população moçambicana ${ }^{17}$ e tendo em conta que a multimistura é pobre nesta vitamina, seria recomendável a incorporação de um alimento que fosse rico neste micronutriente, como por exemplo a manga, que é um produto abundante no país. A vitamina B1 (tiamina) encontra-se presente numa quantidade de $0,61 \mathrm{mg} / 100 \mathrm{~g}$, o que permite classificar a multimistura como um produto rico nesta vitamina. Verificou-se que a quantidade de vitamina B2 (riboflavina) determinada foi extremamente elevada $(11,17 \mathrm{mg} / 100 \mathrm{~g})$. Assim, a multimistura é considerada como um produto rico em riboflavina, segundo a legislação europeia. $\mathrm{O}$ teor de vitamina B3 (niacina) apresentado é extremamente ele- 
nant women between 19 and 30 years old). Although the RDI percentages are low, we can consider that the "multimistura" has potential to meet needs of the target population. In Mozambique, a significant deficiency in vitamin E, vitamin B3, iron and zinc calcium exists. Noticeably, these precise micronutrients are supplied at higher percentages by the "multimistura" intake. The exceptions are vitamin A (deficit leads to growth disturbances, lower resistance to infections and impaired night vision) and calcium (deficit leads to growth delays and osteoporosis in adults $)^{63,64}$. Hence, for pregnant women, we recommend, at least, doubling the daily intake doses of the "multimistura". This recommendation has no negative effects, since vitamin B2 (which would exceed the RDI) is not toxic. Vitamin B2 is water-soluble and, therefore, is excreted in the urine when in excess. Therefore, no limit for daily intake needs to be established ${ }^{63,64,65}$. The RDI percentage both supplied and lacking of each micronutrient, if considering the "multimistura" daily doses currently recommended by the religious congregation ( $15 \mathrm{~g}$ ) for lactating mothers under the age of 18 years and lactating women between 19 and 30 years old is shown in Figure 4.
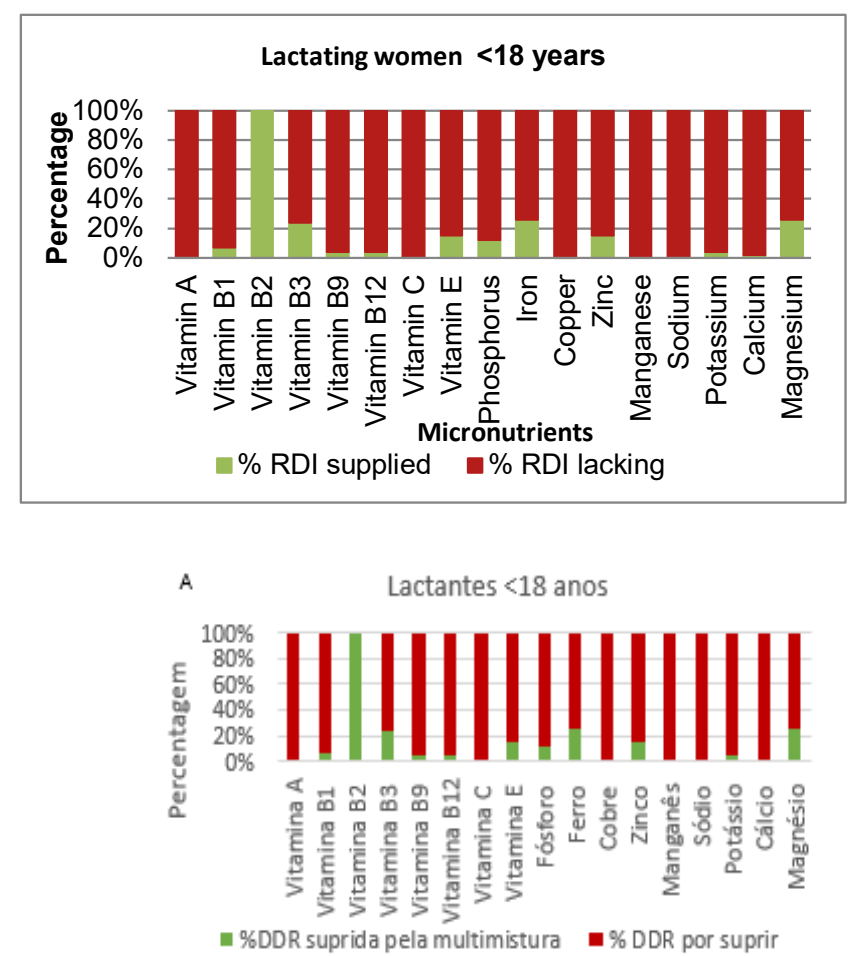

vado (26,79 mg/100 g). Também neste caso, de acordo com a legislação europeia, a multimistura seria considerada um produto rico em niacina, e sendo este um dos micronutrientes que mais comummente se encontra em défice na população moçambicana ${ }^{17}$, o resultado é bastante satisfatório. As vitaminas B9 (ácido fólico) e B12 (cobalamina) apresentaram-se nas quantidades de $0,12 \mathrm{mg} / 100 \mathrm{~g}$ e $0,0007 \mathrm{mg} / 100 \mathrm{~g}$, respetivamente. Estes valores são elevados, fazendo da multimistura um produto rico nestes elementos. A multimistura apresentou um teor de vitamina $\mathrm{C}$ (ácido ascórbico) de 8,16 $\mathrm{mg} / 100 \mathrm{~g}$. A quantidade desta vitamina é tão reduzida que nenhuma alegação nutricional poderia ser feita. A vitamina $E$ (tocoferol) encontra-se presente na multimistura na quantidade de $19,53 \mathrm{mg} / 100 \mathrm{~g}$. Este valor permite classificar o produto como rico nesta vitamina, $\mathrm{e}$, sendo a vitamina $\mathrm{E}$ um dos micronutrientes que mais comummente se apresenta em défice na população moçambicana ${ }^{17}$, cumpriria neste aspeto o objetivo a que se propôs.
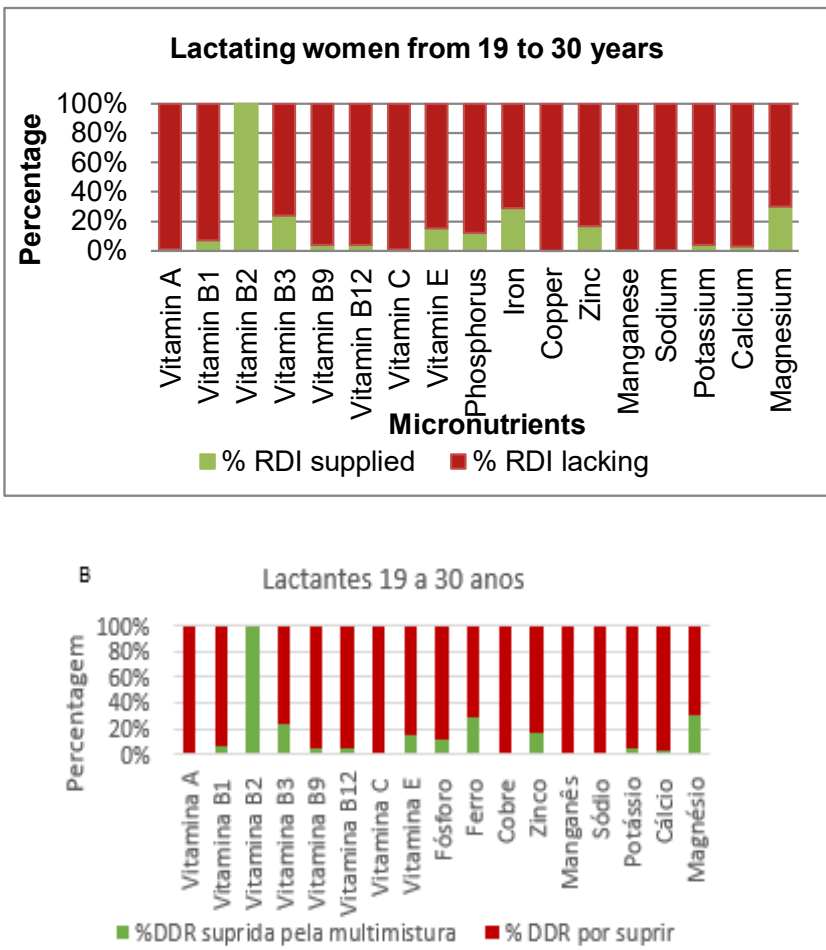

Figure 4/ Figura 4 - Percentage of the RDI supplied and lacking in lactating women from 19 to 30 years (A) and $<18$ years (B) with the ingestion of the multimistura Percentagem da DDR dos micronutrientes, supridas e por suprir com a ingestão da multimistura para lactantes com $<18$ anos (A) e lactantes entre 19 a 30 anos (B). 
Similarly to pregnant women, no differences were disclosed between the two age groups except for the percentage of RDI supplied for matching the needs, which was $12 \%$ and $22 \%$ for the former and the latter, respectively. Generally the recommended $15 \mathrm{~g}$ ingested daily by lactating women did not supply the majority of the RDI. Except for vitamin B12, all percentages stay below $30 \%$ of the RDI. Vitamin B2 overpasses the RDI by $5 \%$ for the recommended doses. Among the micronutrients that are supplied in greater percentages are: vitamin B3 (24\% for both groups), vitamin E (15\% for both groups), phosphorus (12\% for lactating women under 18 years old; $22 \%$ for lactating mothers between 19 and 30 years old), iron ( $26 \%$ for lactating women under 18 years old and $29 \%$ for those with ages ranging from 19 to 30 years), zinc ( $15 \%$ and $17 \%$ for lactating mothers under 18 or between 19 and30 years old, respectively) and magnesium (26\% for lactating women under 18 years old; $30 \%$ for lactating mothers between 19 and 30 years old). The results are similar to those observed in the groups of pregnant women, so similar that common conclusions can be suggested for the two investigated groups.
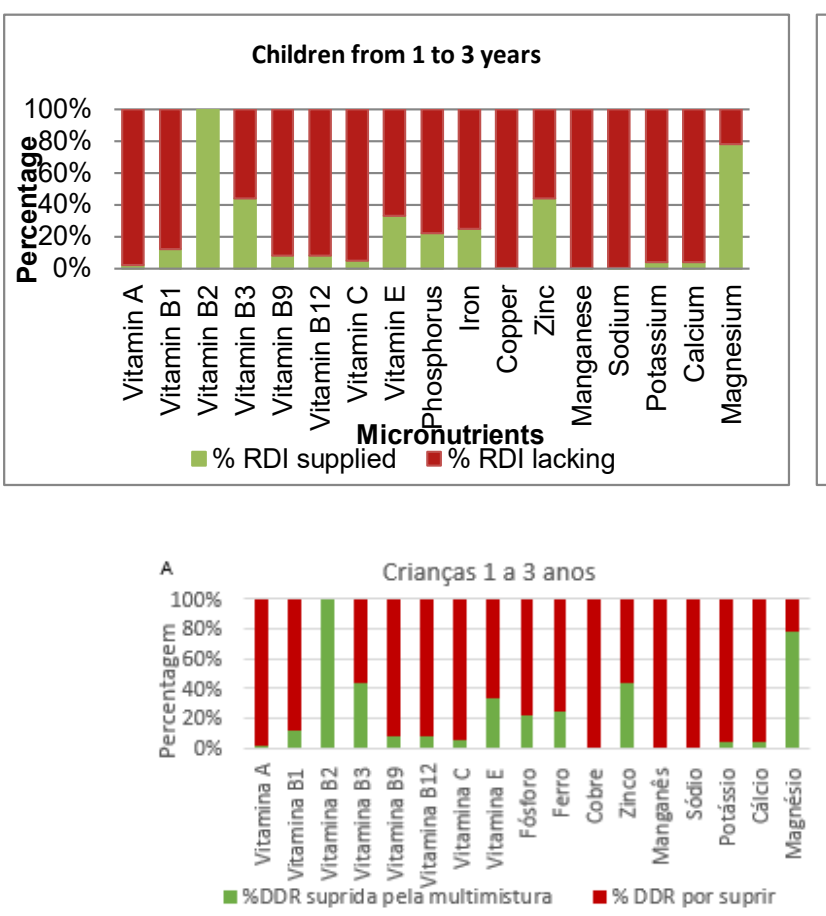

\section{Estimativa da dose diária adequada}

A Figura 3 representa a percentagem das Doses Diárias Recomendadas (DDR) supridas e por suprir de cada micronutriente com a ingestão da multimistura na dose diária recomendada atualmente pela congregação (15 g) para as grávidas com menos de 18 anos e grávidas entre os 19 a 30 anos. Como é possível verificar, não existem diferenças nos resultados entre os dois grupos etários, verificando-se apenas uma diferença na percentagem da DDR suprida com a ingestão da multimistura para o fósforo, que nas grávidas com menos de 18 anos é de $12 \%$ e nas grávidas entre os 19 e 30 anos é de $22 \%$. De um modo geral, os $15 \mathrm{~g}$ de multimistura ingeridos diariamente pelas grávidas não suprem em percentagens elevadas as DDR's dos micronutrientes analisados. Todas as percentagens encontram-se abaixo dos $30 \%$ da DDR, com exceção da vitamina B2, em que o valor da dose diária ingerida com a multimistura ultrapassa em $20 \%$ a DDR. Para além desta vitamina, os micronutrientes em que é suprida uma maior percentagem da sua DDR são: vitamina B3 (22\% -para os dois grupos), vitamina E (20\% -para os dois grupos), fósforo (12\% -grávidas < 18 anos; $22 \%$-grávidas entre os 19 e 30 anos), ferro (10\% -para os dois grupos), zinco (17\% -grávidas $<18$ anos; $18 \%$-grávidas entre os 19 e 30 anos) e magnésio (24\% -grávidas $<18$ anos; $27 \%$ -grávidas entre os 19 e 30 anos).
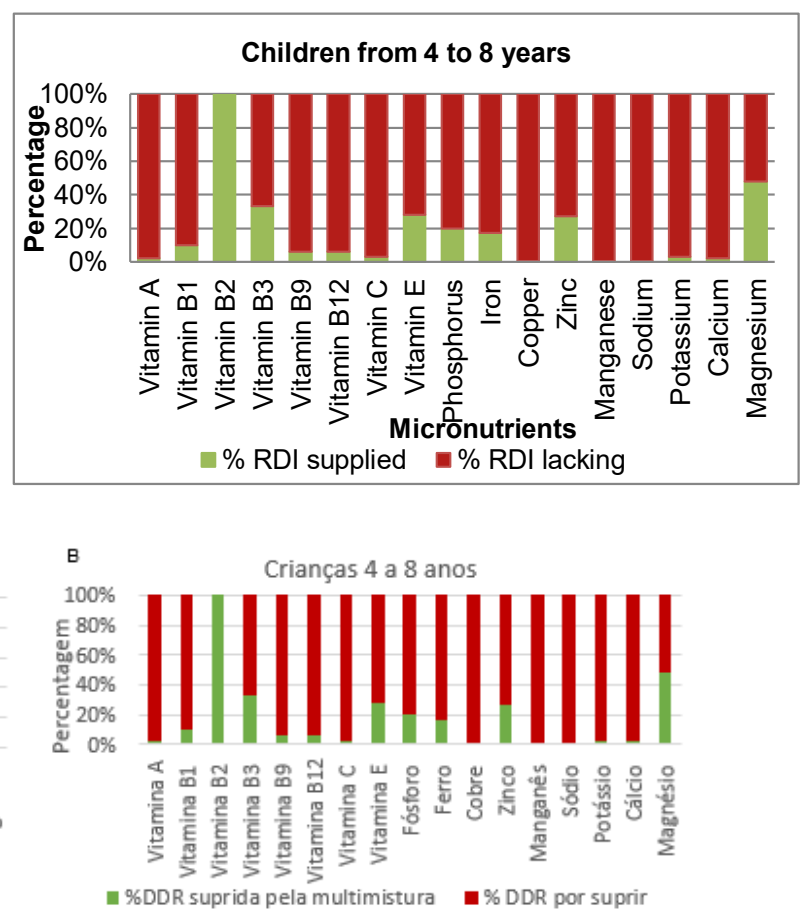

Figure 5/ Figura 5 - Percentage of the RDI supplied and lacking in children from 4 to 8 years (A) and from 1 to 3 years (B) with the ingestion of the multimistura Percentagem da DDR dos micronutrientes, supridas e por suprir com a ingestão da multimistura para crianças entre 1 a 3 anos (A) e crianças entre 4 a 8 anos (B). 
Considering that except for vitamin A and calcium, the "multimistura" is able to meet the nutritional needs of the target population, it is recommended to at least double the daily intake of nutrients by lactating mothers as well.

Regarding the percentage of RDI covered by the currently recommended intake of $10 \mathrm{~g}$ for children between 1 and 3 year-olds and children between 4 and 8 years old (Figure 5), some differences were observed comparing both age segments. Children between the first and the third year of life have their RDI compensated by the recommended doses of "multimistura" at $223 \%, 44 \%, 25 \%, 44 \%$ and $78 \%$, for vitamin B2, vitamin B3, iron, zinc and magnesium, respectively. On the other hand, for children between 4 and 8 years old, these values drop to $186 \%, 33 \%, 17 \%, 27 \%$ and $48 \%$, respectively. It was determined that the $10 \mathrm{~g}$ of "multimistura" daily ingested supply large percentages of micronutrient RDIs, when compared to the other two groups investigated. In this group, higher values, close to $30 \%$, were observed, particularly regarding vitamins B2 and B3, zinc and magnesium as referred earlier, and vitamin E (33\% for children with 1 to 3 years old and $28 \%$ for older children below 8 years old). Among the other micronutrients, those supplying the higher RDI percentages are vitamin B1 $(12 \%$ or $10 \%$ for children in the 1 to 3 years old and 4 to 8 years old segments, respectively), phosphorus ( $22 \%$ for children with 1 to 3 years old and $20 \%$ for older children below 8 years old).

Again, it can be assumed that the supplement will meet needs of the target population, with the exception of vitamin A and calcium. Although these last results are more satisfactory than those from pregnant and lactating women, also for this group an increase in the daily dose of ingested "multimistura" can be advised. However, we do not recommend the intake to be doubled in children below four years old, since it would lead to a magnesium intake higher than the tolerable daily limit established for this group ( $80 \mathrm{mg} / \mathrm{day}$ ), and may result in toxicity and other harmful effects ${ }^{63,64}$. Therefore, the consumption of this product is recommended to stay in a maximum of approximately $13 \mathrm{~g}$ per day. Four to 8 year-old children are no longer susceptible to magnesium toxicity, so, in this group, it is recommended to double the daily ingestion of the product.

\section{Comparison with commercial supplements}

The micronutrients composition delivered by the "multimistura" recommended daily doses for pregnant and lactating women (15 g) was compared with the composition of the recommended daily intake referenced
Apesar das percentagens das DDR's supridas serem baixas, podemos considerar qua a multimistura vai ao encontro das necessidades da população alvo. Em Moçambique existe um grande défice de vitamina A, vitamina $\mathrm{E}$, vitamina $\mathrm{B} 3$, ferro, zinco e cálcio, e são precisamente estes, os micronutrientes que apresentam uma maior percentagem da DDR suprida com a ingestão da multimistura, com exceção da vitamina A (quando esta vitamina se encontra em défice os indivíduos sofrem paragens de crescimento, têm menor resistência a infeções e perdem a visão noturna) e do cálcio (a deficiência de cálcio origina atrasos no crescimento e osteoporose na fase adulta ${ }^{63,64}$. Em resultado desta análise, seria recomendado aumentar, no mínimo para o dobro, a dose diária ingerida de multimistura por parte das grávidas. Esta recomendação pode ser feita uma vez que a vitamina B2 não é tóxica, pois é hidrossolúvel e que excretada na urina quando em excesso, não existindo um limite de ingestão diário estabelecido ${ }^{63,64,65}$.

$\mathrm{Na}$ Figura 4 está representada a percentagem das DDR's supridas e por suprir de cada micronutriente com a ingestão da multimistura na dose diária recomendada atualmente pela congregação (15 g) para as lactantes com menos de 18 anos e lactantes entre os 19 a 30 anos. Como é possível verificar, não existem diferenças nos resultados entre os dois grupos etários, tal como verificado para as grávidas, só se verifica uma diferença na percentagem da DDR suprida com a ingestão da multimistura para o fósforo, que nas lactantes com menos de 18 anos é de $12 \%$ e nas lactantes entre os 19 e 30 anos é de $22 \%$. Assim, de um modo geral, os $15 \mathrm{~g}$ de multimistura ingeridos diariamente pelas lactantes não suprem percentagens elevadas das DDR's dos micronutrientes analisados. Todas as percentagens encontram-se abaixo dos 30\% da DDR, com exceção da vitamina B2, em que o valor da dose diária ingerida com a multimistura ultrapassa em 5\% a DDR desta vitamina. Para além desta vitamina, os micronutrientes em que é suprida uma maior percentagem da sua DDR são: vitamina B3 (24\% -para os dois grupos), vitamina E (15\% -para os dois grupos), fósforo (12\% -lactantes $<18$ anos; $22 \%$ -lactantes entre os 19 e 30 anos), ferro (26\% -lactantes $<18$ anos; $29 \%$-lactantes entre os 19 e 30 anos), zinco (15\% -lactantes $<18$ anos; $17 \%$-lactantes entre os 19 e 30 anos) e magnésio (26\% -lactantes $<18$ anos; $30 \%$ -lactantes entre os 19 e 30 anos). Podemos observar que estes resultados não diferem substancialmente dos resultados obtidos para o grupo das grávidas. Assim, as principais conclusões resultantes para os dois grupos em apreciação são as mesmas, considerando-se que a multimistura vai ao encontro das necessidades nutricionais da população alvo, com exceção para a vitamina A 
on the label of seven commercial supplements targeted to adults, seniors, and pregnant women in industrialized countries: FDC Nutri, FDC Nutri Senior, Pharmaton Vitality, Multivitamins AaZ, Centrum, Centrum Woman and Centrum Mother. Figure 6 shows the twodimensional map of objects distribution in the common area. The results indicate that the studied "multimistura" is superimposed with the FDC Nutri (circle). Thus, we can conclude that the micronutrient content in the recommended "multimistura" daily allowance is not statistically different from recommended daily dose of FDC Nutri. e do cálcio; Recomenda-se assim que se aumente, no mínimo para o dobro, a dose diária ingerida de multimistura por parte das lactantes.

$\mathrm{Na}$ figura 5 está representada a percentagem das DDR's supridas e por suprir de cada micronutriente com a ingestão da multimistura na dose diária de $10 \mathrm{~g}$ recomendada atualmente para as crianças entre o 1 e os 3 anos e crianças entre os 4 e os 8 anos. Contrariamente aos grupos das grávidas e lactantes, para as crianças existem algumas diferenças nos resultados obtidos para os dois grupos etários.
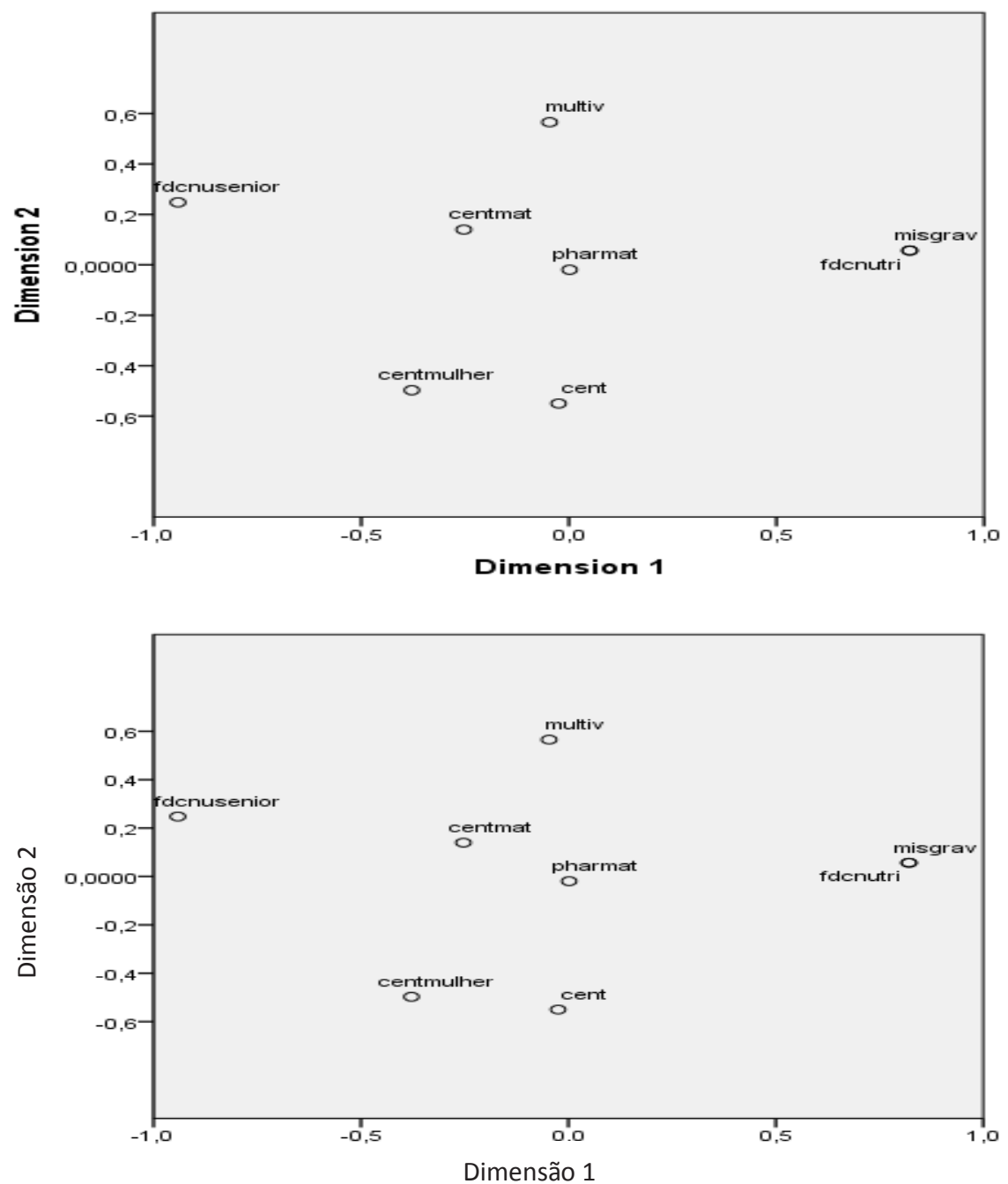

Figure 6/ Figura 6 - The two-dimensional map of objects distribution in the common area. The studied "multimistura" is superimposed with the FDC Nutri (circle).

Legend: FDC nutri senior- fdcnusenior; Centrum woman- centmulher; Centrum mother- centmat; Multivitamins AaZ- multiv; Pharmaton vitality- pharmat; Centrum- cent; FDC nutri- fdcnutri; Multimisturamisgrav

Mapa percetual bidimensional obtido dos produtos em estudo no espaço comum. O círculo indica sobreposição da multimistura com o suplemento FDC nutri.

Legenda: FDC nutri senior- fdcnusenior; Centrum mulher- centmulher; Centrum materna- centmat; Multivitaminas AaZ- multiv; Pharmaton vitalidade- pharmat; Centrum- cent; FDC nutri- fdcnutri; Multimistura- misgrav. 
This stands as very interesting result since this supplement has no specific target, which demonstrates that, in general, the "multimistura" delivers a balanced composition and has the potential to be directed to any individual. On the oposite side, the farthest object from the "multimistura" was FDC Nutri Senior, with a distance in space of 1.773. This result was not unexpected since FDC Nutri Senior is directed to an older population, with distinct nutritional requirements. Ideally, one would expect the "multimistura" to be similar to Centrum Mother (1.077 distance) since this specific supplement is targeted to pregnant and lactating women.

Concerning children aged between 1 and 8 years old, the micronutrients composition delivered via consumption of the recommended daily dose $(10 \mathrm{~g})$ has been compared with the composition of the referenced dose on the label of three commercial supplements targeted to this age group in the developed countries: FDC Nutri Kids, Juvamine Top form and Centrum Junior. Figure 7 illustrates the one-dimensional map object distribution in the common area, which shows that the studied dietary plants supplement is closest to Centrum Junior (circle), at a distance of 0.561. Conversely, the most dissimilar supplement was FDC Nutri Kids, with a calculated distance of 1.602. However, these Euclidian distances are sufficiently low (even though products direct to the same target audience and that theoretically should be nearly identical) to be considered as forming a homogeneous group. We can, hence, conclude that micronutrients composition delivered by in the recommended daily intake of $10 \mathrm{~g}$ for children is not statistically different from the composition of the recommended daily intake of these commercial supplements.

\section{Final Remarks}

Considering the nutritional needs of the Mozambican population, the dietary supplement assessed can be considered as a suitable product for the target population. Framed in the "dehydrated product" category, with associated stability from the microbial risk point of view, the product was shown to have high levels of macronutrients and a high caloric value. Except vitamin A, all micronutrients in which a high percentage of the Mozambican population are commonly lacking (iron, zinc, calcium, vitamin B3 and vitamin E) were quantified in high levels. Using the European legislation criteria, the "multimistura" investigated would be considered an iron-, zinc-, vitamin B3- and vitamin E-rich product ( $100 \mathrm{~g}$ of $\geq 30 \%$ of nutrients supplying DDR). Regarding calcium, the product would be considered as "source". The low amounts of vitamin A means that, according to the European legislation, no nutrition
Para as crianças entre o primeiro e os 3 anos de idade, a percentagem da DDR suprida com a ingestão de $10 \mathrm{~g}$ de multimistura para a vitamina B2, vitamina B3, ferro, zinco e magnésio são de $223 \%, 44 \%, 25 \%, 44 \%$ e $78 \%$, respetivamente. Por outro lado, para as crianças entre os 4 e 8 anos de idade estes valores baixam para $186 \%$, $33 \%, 17 \%, 27 \%$ e $48 \%$, respetivamente. Constatamos que, de um modo geral, os $10 \mathrm{~g}$ de multimistura ingeridos diariamente pelas crianças suprem maiores percentagens das DDR's dos micronutrientes analisados, em comparação com os outros dois grupos estudados.

Existem neste grupo valores superiores/próximos dos $30 \%$, nomeadamente no que diz respeito à vitamina $\mathrm{B} 2$, vitamina $\mathrm{B} 3$, zinco e magnésio referidos anteriormente, e à vitamina $\mathrm{E}(33 \%$-crianças 1 a 3 anos; $28 \%$-crianças dos 4 a 8 anos). Além destes micronutrientes, os micronutrientes que suprem uma maior percentagem da DDR são a vitamina B1 (12\% -crianças 1 a 3 anos; $10 \%$ -crianças dos 4 a 8 anos), o fósforo (22\% -crianças 1 a 3 anos; 20\% -crianças dos 4 a 8 anos) e o ferro (referido anteriormente). Mais uma vez, pode ser considerado que a multimistura vai ao encontro das necessidades da população alvo, com exceção da vitamina A e do cálcio. Apesar destes resultados serem mais satisfatórios do que para os grupos anteriores, também para este grupo seria recomendado o aumento da dose diária ingerida de multimistura. Contudo, na faixa etária entre o 1 e os 3 anos, não é recomendável o fornecimento do dobro da dose ingerida, uma vez que a ingestão de magnésio passaria a ser superior ao limite de ingestão diário aceitável estabelecido para este grupo $(80 \mathrm{mg} / \mathrm{dia})$, podendo tornar-se tóxico e exercer efeitos nocivos ${ }^{63,64}$. Deste modo, o aumento do consumo deste produto seria recomendado para um máximo de aproximadamente $13 \mathrm{~g}$ por dia. No grupo etário entre os 4 e 8 anos o problema da toxicidade do magnésio já não se coloca, sendo neste caso recomendado duplicar a dose diária ingerida de multimistura.

\section{Comparação com suplementos alimentares comerciais}

A composição em micronutrientes presente na dose diária recomendada atualmente para grávidas e lactantes $(15 \mathrm{~g})$ foi comparada com a composição da dose diária recomendada (referenciada no rótulo) de sete suplementos alimentares comerciais direcionados para adultos, seniores, mulheres e grávidas no 'mundo ocidental': FDC nutri, FDC nutri senior, Pharmaton vitalidade, Multivitaminas AaZ, Centrum, Centrum mulher e Centrum materna. Na comparação entrou-se em conta com os micronutrientes quantificados no presente trabalho para a multimistura. Na Figura 6 apresenta-se o mapa percetual bidimensional obtido dos objetos no es- 

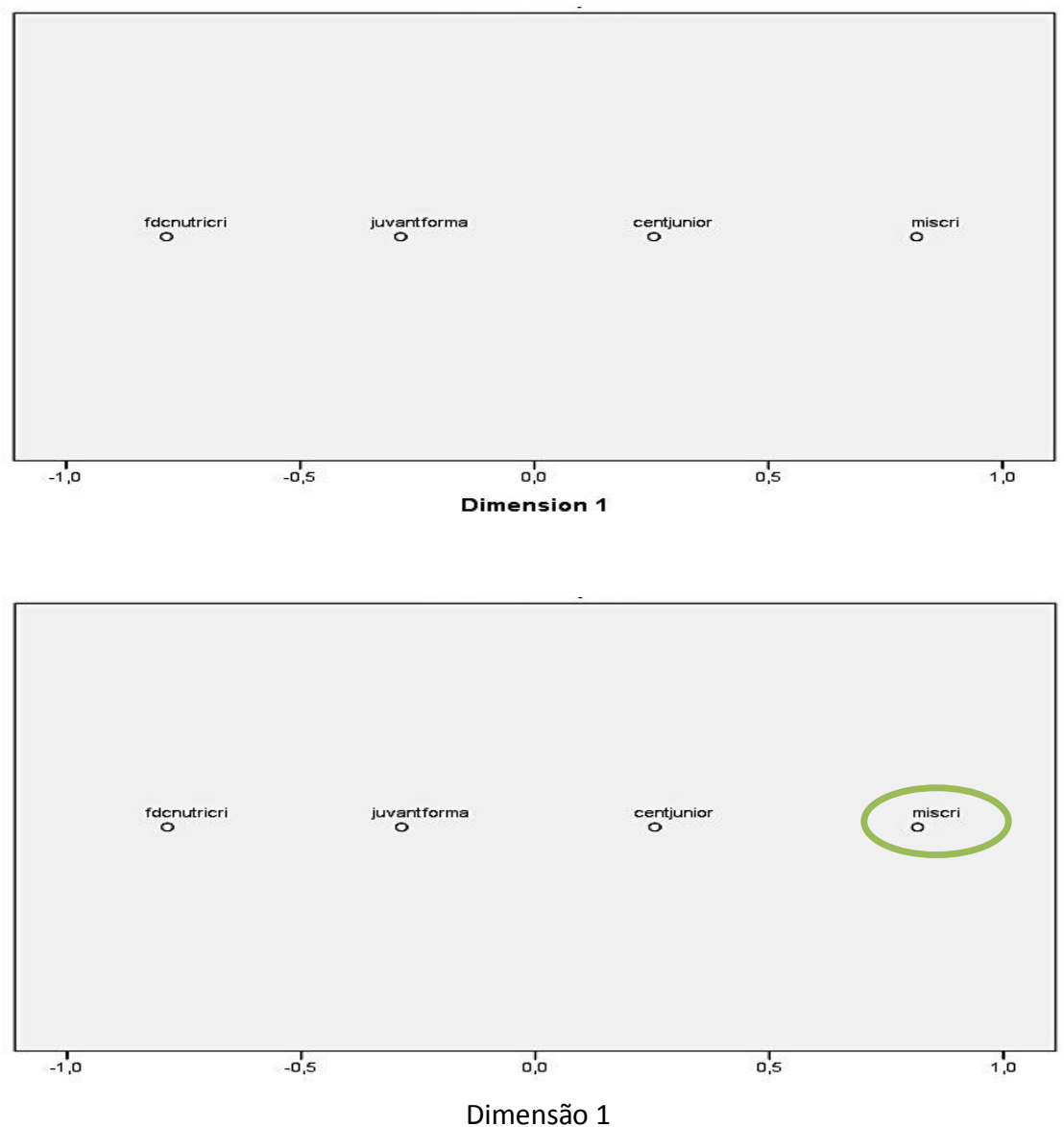

Figure 7/ Figura 7 - The one-dimensional map objects distribution in the common area. The studied dietary plants supplement is closest to Centrum Junior (circle).

Legend: FDC nutri kids- fdcnutricri; Juvamine top form- juvantforma; Centrum junior- centjunior; Multimistura- miscri

Mapa percetual unidimensional obtido dos produtos em estudo no espaço comum. O círculo indica a posição da multimistura no espaço comum.

Legenda: FDC nutri kids- fdcnutricri; Juvamine top forma- juvantforma; Centrum junior- centjunior; Multimistura- miscri.

claim can be stated. Thus, the incorporation of vitamin A- and calcium-rich ingredients is recommended. The analyses of the DRI's percentage that is compensated by the "multimistura" intake in each target group, it can be concluded that the currently recommended doses are not sufficient. Our results recommend that the daily doses should be, at least, doubled, except for the children aged 1 to 3 years old, due to the limit of tolerated magnesium intake. The "multimistura" was shown to be similar to some commercial supplements in its micronutrient and vitamins balance. It can be concluded that, using the recommended doses for pregnant and for lactating women, the supplement shows no differences regarding the DRD when compared to the commercial food supplement FDC Nutri. On the other hand, paço comum, que mostra que a multimistura se encontra sobreposta no espaço comum com o suplemento FDC nutri (indicado pelo círculo). Assim, podemos concluir que o teor dos micronutrientes analisados presentes na dose diária recomendada de multimistura não é estatisticamente diferente da composição da dose diária recomendada do suplemento FDC nutri. Este resultado é satisfatório uma vez que este suplemento não tem nenhum público-alvo específico, demonstrando que de um modo geral a multimistura apresenta uma composição equilibrada e poderia direcionar-se a qualquer tipo de indivíduo. O objeto que se encontra mais afastado da multimistura é o FDC nutri senior, com uma distância de 1,773. Este resultado era esperado uma vez que a FDC nutri senior se destina a uma população mais ido- 
the composition delivered by the recommended dosage for children was shown to be statistically closer to the DRD's commercial food supplement Centrum Junior. In addition to its nutritional value, the "multimistura" can be considered to be a nutraceutical product, due to its high levels of biologically active compounds and phytochemicals (carotenoids and phenolics) and due to its powerful antioxidant capacity, which are known to be highly beneficial to health.

\section{Acknowledgements}

The authors acknowledge "Instituto de Solidariedade e Cooperação Universitária (ISU)" NGO and "Laboratório 10 do Agrupamento Funcional Química e Ambiente do Departamento de Ciências e Engenharia de Biossistemas - Instituto Superior de Agronomia", and from "Laboratório de Microbiologia - Instituto Nacional de Investigação Agrária e Veterinária", in Lisbon, teams. This work was partially funded by the International Rice Research Institute (IRRI, Mozambique) under the "FrutosNativos4SAN" program framework.

\section{Conflict of interests}

The authors declare that there is no financial or personal relationship that can be understood as presenting a potential conflict of interest. sa, com necessidades nutricionais distintas. Idealmente, seria de esperar que a multimistura se tivesse mostrado semelhante ao suplemento Centrum materna (apresentou uma distância de 1,077 da multimistura) uma vez que se trata de um suplemento específico para grávidas e lactantes.

No caso das crianças com idades entre 1 e os 8 anos, a composição de micronutrientes presente na dose diária recomendada atualmente $(10 \mathrm{~g})$ de multimistura foi comparada com a composição da dose referenciada no rótulo de três suplementos alimentares comerciais direcionados para esta faixa etária em países do 'mundo ocidental': FDC nutri kids, Centrum junior e Juvamine top forma. Na figura 7 representa-se o mapa percetual unidimensional obtido dos objetos no espaço comum, onde é possível verificar que o suplemento que se encontra mais próximo da multimistura (representada por um círculo), é o Centrum junior, que se apresenta a uma distância de 0,561 , e o suplemento que se encontra mais afastado é o FDC nutri kids, com uma distância de 1,602. Por estas distâncias serem tão curtas e por os próprios suplementos alimentares comerciais apresentarem distâncias entre si (mesmo sendo produtos que se direcionam para o mesmo público alvo e que teoricamente não deveriam apresentar distâncias entre si), formando um grupo homogéneo e com distâncias euclidianas muito baixas, podemos concluir que a composição de micronutrientes presente na dose diária recomendada de $10 \mathrm{~g}$ atualmente para as crianças não se apresenta estatisticamente diferente da composição da dose diária recomendada destes suplementos alimentares comercias.

\section{Conclusões}

Considerando as necessidades nutricionais da população moçambicana, a multimistura avaliada revelou ser um produto adequado à população alvo. Enquadrou-se na categoria de produto desidratado com caraterísticas que lhe conferem estabilidade do ponto de vista microbiano, apresentou elevados teores de macronutrientes e um elevado valor calórico. Todos os micronutrientes que se apresentam mais comummente em défice na população moçambicana (ferro, zinco, cálcio, vitamina A, vitamina B3 e Vitamina E) apresentam-se em teores elevados, com exceção da vitamina $\mathrm{A}$. De acordo com as obrigatoriedades legais europeias a multimistura seria considerada um produto rico em ferro, zinco, vitamina B3 e vitamina E (100 g de multimistura suprem $\geq 30 \%$ da DDR). Só se poderia alegar que a multimistura seria uma fonte de cálcio. $\mathrm{O}$ valor de vitamina $\mathrm{A}$ é tão baixo que nenhuma alegação nutricional, de acordo com a le- 
gislação europeia, sobre a quantidade deste micronutriente na multimistura poderia ser feita. Assim, recomenda-se a incorporação na multimistura de elementos ricos em vitamina A e cálcio. Quando analisada a percentagem das DDR's suprida com a ingestão da multimistura para cada um dos grupos, podemos concluir que as doses recomendadas atualmente são baixas. Recomenda-se que no mínimo se deva duplicar as doses diárias recomendadas exceto para o grupo das crianças entre o 1 e os 3 anos, devido ao limite de ingestão máximo admissível de magnésio. A multimistura apresentou-se semelhante a alguns suplementos alimentares comerciais. Concluiu-se que, na dose atualmente recomendada para grávidas e lactantes, a multimistura apresenta uma composição estatisticamente não diferente da composição da DDR do suplemento alimentar comercial FDC nutri. Já na comparação realizada com a dose recomendada para crianças, a composição da multimistura apresentou estiticamente a menor diferença com a composição da DDR para o suplemento alimentar comercial Centrum junior. Para além do fator nutricional a multimistura poderia ser considerada um produto nutracêutico, pois apresentou elevados teores de compostos fitoquímicos biologicamente ativos (carotenóides e fenóis) benéficos e um elevado poder antioxidante.

\section{Agradecimentos}

Os autores agradecem à ONGD Instituto de Solidariedade e Cooperação Universitária (ISU) e às equipas do Laboratório 10 do Agrupamento Funcional Química e Ambiente do Departamento de Ciências e Engenharia de Biossistemas do Instituto Superior de Agronomia, e do Laboratório de Microbiologia do Instituto Nacional de Investigação Agrária e Veterinária, Lisboa. Este trabalho foi parcialmente financiado pelo International Rice Research Institute (IRRI, Moçambique) no âmbito do Programa "FrutosNativos4SAN".

\section{Conflito de Interesses}

Os autores declaram que não têm relações financeiras ou pessoais que possam ser entendidas como apresentando um conflito potencial de interesses. 


\section{References/ referências}

1. UN Millennium Project. Halving hunger: it can be done. London and Sterling, VA: Task Force on Hunger; 2005.

2. World Bank. Repositioning nutrition as central to development. A strategy for large-scale action. Washington DC: World Bank; 2006.

3. UNEP. United Nations Environment Programme. Avoiding Future Famines: Strengthening the Ecological Foundation of Food Security through Sustainable Food Systems. Nairobi: UNEP; 2012.

4.Santos JL, Carmo I, Graça P, Ribeiro I. Introdução: Uma alimentação com futuro, saudável, sustentável e acessível para todos. In: Santos JL, Carmo I, Graça P, Ribeiro I, editors. O Futuro da Alimentação: Ambiente, Saúde e Economia. Lisboa:Fundação Calouste Gulbenkian; 2013. p.7-16.

5. Muthayya S, Rah JH, Sugimoto JD, Ross FF, Kraemer K, Black RE. The Global Hidden Hunger Indices and Maps: An Advocacy Tool for Action. PlOS One 2013; 8(6).

6. Black RE, Allen LH, Bhutta ZA, Caulfield LE, de Onis M, Ezzati M, Mathers C, Rivera J. Maternal and child undernutrition: global and regional exposures and health consequences. The Lancet 2008; 371:243-260.

7. Black RE, Victora CG, Walker SP, Bhutta ZA, Christian P, de Onis M, Ezzati M, GranthamMcGregor S, Katz J, Martorell R, Uauy R, Maternal and Child Nutrition Study Group. Maternal and child undernutrition and overweight in low-income and middle-income countries. The Lancet 2013; 382:427-51.

8. The Lancet. The Lancet's Series on Maternal and Child Undernutrition- Executive Summary. 2008.

9. UN. United Nations. Relatório sobre os Objectivos de Desenvolvimento do Milénio 2014 [cited 2014 Aug 20] in: URL: https://www. unric.org/pt/

10. Braun JV. Prefácio. In: Hidden Hunger. Berlim: Springer-Verlag Berlin and Heidelberg GmbH \& Co. KG; 2013.

11. Sight and life. Hidden Hunger [cited 2014 Apr 7] in: URL: http://www.sightandlife. org/fields-of-work/hidden-hunger.html

12. Godfray C. O desafio de alimentar nove mil milhões de pessoas em 2050. In: Santos JL, Carmo I, Graça P, Ribeiro I, editors. O Futuro da Alimentação: Ambiente, Saúde e Economia. Lisboa:Fundação Calouste Gulbenkian; 2013. p.18-32.

13. Instituto Nacional de Estatística, IP (INE). Estatísticas da CPLP 2003-2010. Comunidade de Países de Língua Portuguesa: breve retrato estatístico 2013 [cited 2014 Feb 20]. in: URL: http://www.ine.pt/ngt_server/attachfileu.jsp?look_parentBoui=161941931\&att_ display $=$ n\&att_download $=\mathrm{y}$

14. CIA. Central Intelligence Agency. The World Factbook, Africa, Mozambique. [cited 2014 March 18]. in: URL: https://www.cia.gov/library/publications/the-world-factbook/geos/ mz.html
15. International Food Policy Research Institute, Concern Worldwide, Welthungerhilfe \& Institute of Development Studies. Global Hunger Index. The Challenge Of Hunger: Building Resilience To Achieve Food And Nutrition Security. Bonn/Washington, DC/ Dublin; 2013.

16. WHO \& FAO. Diet, nutrition and the prevention of chronic diseases. Report of a joint WHO/FAO Expert Consultation. WHO Technical Report Series 916. Geneva:World Health Organization; 2003.

17. FAO. Mozambique Nutrition Profile. Nutricion and Consumer Protection Division; 2011.

18. Beausset I. Estudio de las Bases Científicas para el Uso de Alimentos Alternativos en la Nutrición Humana. [S.I.]: INAN/UNICEF; 1992.

19. Bittencourt SA. Uma alternativa para política nutricional brasileira? Cad Saúde Pública Rio de Janeiro 1998; 14:629-636.

20. Madruga MS, Santos HB, Bion FM, Antunes NLM. Avaliação Nutricional de uma Dieta Suplementada com Multimisturas: Estudo em Ratos. Cienc Tecnol Aliment Campinas 2004; 24:129-133.

21. Kaminski TA, Bagetti M, Silva LP, Callegaro MGK, Fell ER. Avaliação dos Elementos Tóxicos, Antinutricionais e Patógenos em Multimisturas. Alim Nutr Araraquara 2006; 17:171-9.

22. Brandão CT, Brandão RF, Lulkin C, Gaudino MA, Brandão E. Alimentação Alternativa. Brasília:Centro Pastoral Popular de Goiania; 1996.

23. Santos LAS, Lima AMP, Passos IV, Santos LMP, Soares MD, Santos SMC. Uso e percepções da alimentação alternativa no Estado da Bahia: um estudo preliminar. Rev Nutr, Campinas 2001; 14:35-40.

24. Thompson B, Amoroso L. Combating Micronutrient Deficiencies: Food-Based Approaches. Published jointly by $\mathrm{CAB}$ International and FAO; 2011.

25. Leitzmann C, Watzl B. Other biologically active substances in plant foods: phytochemicals. In: Mann J, Truswell S, editors. Essentials of Human Nutrition. 3 rd ed. New York:Oxford University Press; 2007. p.222232.

26. Ferreira HS, Cavalcante SA, Assunção ML. Composição Química e Eficácia da Multimistura como Suplemento Dietético: revisão da literatura. Ciência \& Saúde Coletiva 2010; 15: 3207-32.

27. AOAC. Association of Official Analytical Chemists. Official Methods of Analysis. 14 th ed. Arlington:Association of Official Analytical Chemists, Inc; 1984.

28. Vandecasteele C, Block CB. Modern Methods for Trace Element Determination. Chichester:John Wiley \& Sons; 1993.
29. Van Soest PJ, Robertson JB, Lewis BA. Methods for dietary fiber, neutral detergent fiber, and nonstarch polysaccharides in relation to animal nutrition. J Dairy Sci Savoy 1991; 74:3583-3597.

30. Dorleans M. Descriptif dum ode opératoire de la méthode Van Soest adaptée à l'analyse des aliments concentrés. Cah. Tech 1985; INRA- 11.

31. IUPAC. International Union of Pure and Applied Chemistry. Standard methods for the analysis of oils, fats and derivatives. 6 th ed. Oxford:PergamonPress; 1979.

32. Ramalho JC, Pons TL, Groenveld HW, Nunes MA. Photosynthetic responses of Coffea arabica L. leaves to a short term high light exposure in relation to $\mathrm{N}$ availability. Physiol Plant 1997; 101:229-239.

33. Acosta O, Pérez AM, Vaillant, F. Chemical characterization, antioxidante properties, and volatile constituents of naranjilla (Solanum quitoense Lam.) cultivated in Costa Rica. Arch Latinoam Nutr 2009; 59:88-94.

34. Swain T, Hillis WE. The phenolic constituents of Purmus domestica I. The quantitative analysis of phenolic constituents. J Sci Food Agric 1959; 10:63-8.

35. Brand-Wiliams W, Cuvelier ME, Berset C. Use of a free radical method to evaluate antioxidant activity. LWT - Food Sci Technol 1995; 28:25-30.

36. Miller NJ, Diplock AT, Rice-Evans C, Davies MJ, Gopinathan V, Milner A. A novel method for measuring antioxidant capacity and its application to monitoring the antioxidant status in premature neonates. Clinical Sci 1993; 84:407-412.

37. Romero-Rodrigues A, Oderiz LA, Hernandez JL, Gandara S. Comparaison de deux méthodes de dosage par CLHP de l'ácide ascorbique dans Carica pentagona. Sciences des Aliments 1992; 12:593-600.

38. Havaux M, Kloppstech K. The protective functions of carotenoid and flavonoid pigments against excess visible radiation at chilling temperature investigated in Arabidopsis npq and tt mutants. Planta 2001; 213:953-966.

39. Fernando SM, Murphy PA. HPLC determination of thiamin and riboflavin in soybeans and tofu. J Agric Food Chem 1990; 38:1637.

40. NIH. National Institutes of Health. Nutrient Recommendations: Dietary Reference Intakes (DRI). Tables: Elements (Minerals) [cited 2014 Mar 2] in: URL: http://www.iom. edu/Global/News\%20Announcements/ /me dia/48FAAA2FD9E74D95BBDA2236E738 7B49.ashx 
41. NIH. National Institutes of Health. Nutrient Recommendations: Dietary Reference Intakes (DRI) Tables: Elements (Vitamins) [cited 2014 May 2] in: URL: http://ods. od.nih.gov/Health_Information/Dietary_ Reference Intakes.aspx

42. Meulman $\bar{J}$. The Integration of multidimensional scaling and multivariate analysis with optimal transformation of variables. Psychometrika 1992; 57:539-565

43. Prabhakar K. Intermediate Moisture Foods. In: Robinson RK, editor. Encyclopedia of Food Microbiology 2 nd ed. Academic Press; 2014. p.371-6.

44. ANVISA. Agência Nacional de Vigilância Sanitária. Resolução RDC nº263 de 22 de Setembro de 2005. Regulamento Técnico para Produtos de Cereais, Amidos, Farinhas e Farelos. Diário Oficial da União, Brasília, DF, 23 Set. 2005; 1:368-9.

45. Adams MR, Moss MO. Food Microbiology. 3 rt ed. Guildford:RSC Publishing; 2008.

46. Kim MY, Kim EJ, Kim Y, Choi C, Lee B. Comparison of the chemical compositions and nutritive values of various pumpkkin (Cucurbitaceae) species and parts. Nutr Res Pract 2012; 6:21-27.

47. Nzikou JM, Matos L, Bouanga-Kalou G, Ndangui CB, Pambou-Tobi NPG, Kimbonguila, A., Silou T, Linder M, Desobry S. Chemical composition on the seeds and oil of sesame (Sesamum indicum L.) grown in Congo-Brazzaville. Adv J Food Sci Technol 2009; 1:6-11.

48. Fradinho P, Raymundo A, Sousa I. Estabilização enzimática do óleo de farelo de arroz. In: Sousa I, Raymundo A, Prista C, Alves V, editors. $12^{\circ}$ Encontro de Química dos Alimentos. Composição Química, Estrutura e Funcionalidades: A Ponte Entre Alimentos Novos e Tradicionais. Lisboa:Sociedade Portuguesa de Química; 2014. p.26-9.

49. Borges AM, Pereira J, Lucena EMP. Caracterização da farinha de banana verde. Ciênc Tecnol Aliment 2007; 29:333-9.

50. Teixeira EMB, Carvalho MRB, Neves VA, Silva MA, Arantes-Pereira L. Chemical characteristics and fractionation of proteins from Moringa oleifera Lam. leaves. Food Chem 2013; 147:51-4.

51. Modesti CF, Corrêa AD, Oliveira ED, Abreu CMP, Santos CD. Caracterização de concentrado protéico de folhas de mandioca obtido por precipitação com calor e ácido. Ciênc Tecnol Aliment Campinas 2006; 27:464469.
52. Sun H, Mu T, Xi L, Zhang M, Chen J. Sweet potato (Ipomoea batatas L.) leaves as nutritional and functional foods. Food Chem 2014; 156:380-9.

53. Gonsalves PE. Livro dos Alimentos. São Paulo:MG Editores; 1992.

54. Instituto Nacional de Saúde Doutor Ricardo Jorge. Tabela da Composição de Alimentos [cited 2014 Sep 10] in: URL: http://www. insa.pt/sites/INSA/Portugues/AreasCientificas/AlimentNutricao/AplicacoesOnline/ TabelaAlimentos/Paginas/TabelaAlimentos. aspx

55. Souza CO, Menezes JDS, Neto DCR, Assis JGA, Silva SR, Druzian JI. Carotenoides totais e vitamina A de cucurbitáceas de Banco Ativo de Germoplasma da Embrapa Seminárido. Ciência Rural 2010; 4480.

56. Kidmose U, Knuthsen P, Edelenbos M, Justesen U, Hegelund E. Carotenoids and flavonoids in organically grown spinach (Spinacia oleracea L) genotypes after deep frozen storage. J Sci Food Agric 2001; 81:918-923.

57. Stringheta PC, Nachtigall AM, Oliveira TT, Ramos AM, Sant'ana HMP, Gonçalves MPJC. Luteína: propriedades antioxidantes e benefícios à saúde. Alim Nutr Araraquara 2006; 17:229-238.

58. Kaulmann A, Jonville MC, Schneider YJ, Hoffmann L, Bohn T. Carotenoids, polyphenols and micronutriente profiles of Brassica oleraceae and plum varieties and their contribution to measures of total antioxidant capacity. Food Chem 2013; 155:240-250.

59. Floegel A, Kim DO, Chung SJ, Koo SI, Chun OK. Comparison of ABTS/DPPH assays to measure antioxidant capacity in popular antioxidant-rich US foods. J Food Composition and Analysis 2010; 24:1043-8

60. Regulamento CE N ${ }^{\circ} 1924 / 2006$ do Parlamento Europeu e do Conselho de 20 de Dezembro de 2006 relativo às alegações nutricionais e de saúde sobre os alimentos.
61. Cozzolino SMF. Biodisponibilidade de nutrientes. Barueri:Manole; 2005.

62. NIH National Institutes of Health. Vitamin A- Fact Sheet for Health Professionals [cited 2014 May 2] in: URL: http://ods.od.nih.gov/ factsheets/VitaminA-HealthProfessional/

63. Sizer FS, Whitney EN. Nutrição- Conceitos e Controvérsias. 8 th ed. Barueri:Manole; 2000.

64. Lidon F, Silvestre MM. Princípios de Alimentação e Nutrição Humana. Lisboa:Escolar Editora; 2010.

65. Ricardo CPP, Teixeira ARN. Moléculas Biológicas - estrutura e propriedades. 4 th ed. Lisboa: Plátano Editora; 1993. 